Iranian Quarterly Journal of Breast Disease. 2019; 12(3):39.

\section{Original Article \\ Effect of Acceptance and Commitment Therapy on Sexual Desire in Women with Breast Cancer after Mastectomy}

\author{
Ghasemi L ${ }^{1}$, Jabalameli $\mathrm{Sh}^{{ }^{*}}$ \\ ${ }^{1}$ Department of Psychology, Najafabad Branch, Islamic Azad University, Najafabad, \\ Iran
}

Receive: $13 / 2 / 2019$

Accepted: 21/8/2019

*Corresponding Author: sh.jabalameli@yahoo.com

Ethics Approval: Not applicable

\begin{abstract}
Introduction: The effects of breast cancer and mastectomy on sexuality, an important aspect of personality, emphasize the need for psychological treatments. The purpose of this study was to investigate the effectiveness of acceptance and commitment therapy (ACT) on sexual desire in breast cancer patients after mastectomy.
\end{abstract}

Methods: This was a semiexperimental study with an experimental and a control group with a pretest-posttest design. The statistical population included all women with breast cancer in the Isfahan province who had come to Alla charity center in 2017. A sample of 26 women with breast cancer was selected through available sampling and assigned randomly to two groups of 13 subjects each. The experimental group received ACT over 8 sessions and the control group remained on the waiting list until the end of the study. The measurement tool was the Hurlbert Index of Sexual Desire administered before and after the intervention. Data were analyzed with SPSS 16 using an analysis of covariance test.

Results: There was a significant difference in the mean scores on sexual desire between the two groups $(F=7.99, p=0.014)$. The mean score on sexual desire improved from 0.85 to 1.23 in the treatment group, but there was no change in the control group (1.17 in the pretest vs 1.16 in the posttest). In general, ACT was effective in improving sexual desire in patients ( $p<0.05$, effect size: 0.48$)$.

Conclusion: In general, according to the findings of this research, ACT seems to be effective in improving psychological problems in women with breast cancer.

Keywords: Acceptance and Commitment Therapy, Sexual Desire, Breast Cancer, Mastectomy 


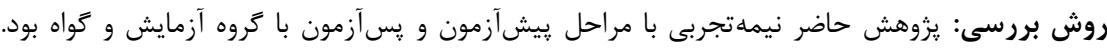

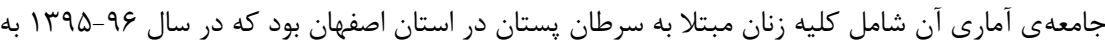

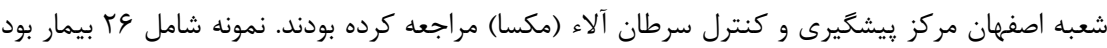

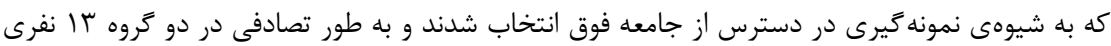

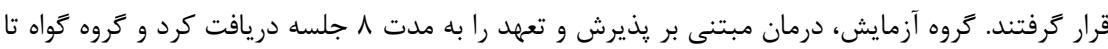

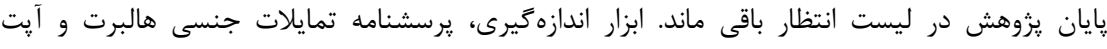

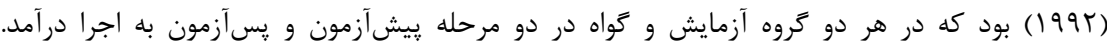

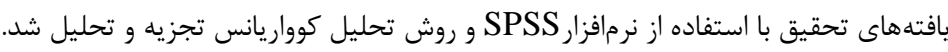

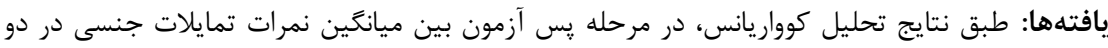

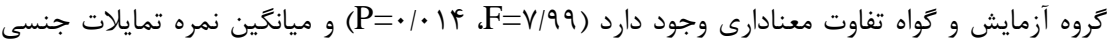

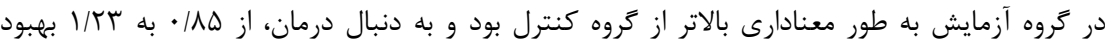

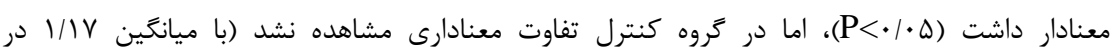

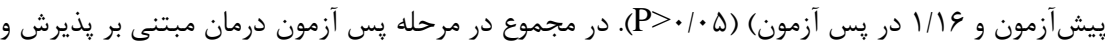

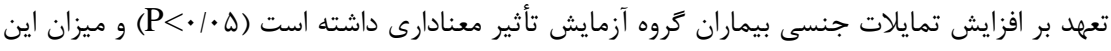
نأثير ^^| • بود. نتيجهَيرى: به طور كلى با توجه به نتايج اين يُوهش، احتمالا بتوان از درمان مبتنى بر يذيرش و تعهد

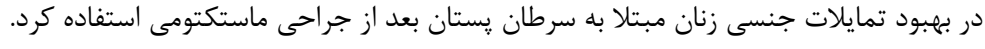
أوازههاى كليدى: درمان، پذيرش و تعهد، تمايلات جنسى، سرطان پِتان، جراحى ماستكتومى

تاريخ ارسال: TV/I/TF تاريخ يذيرش: •

" نويسنده مسئول: sh.jabalameli@yahoo.com 
(9). مطالعه شيرد نيز به وضوح نشاندهنده اين حقيقت

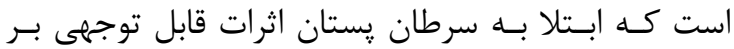

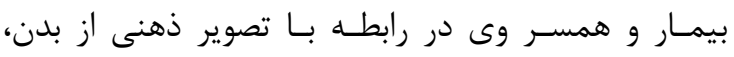

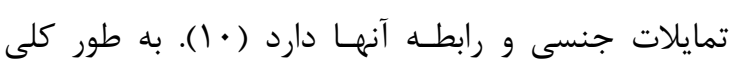

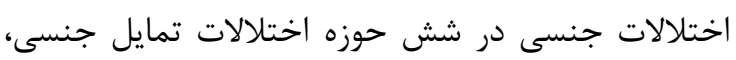

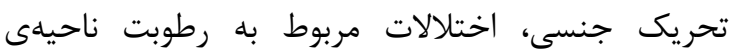

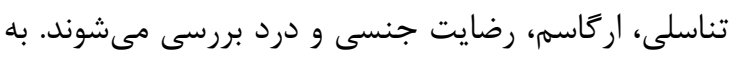

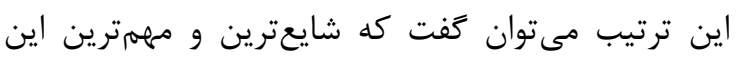

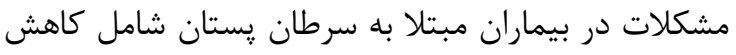

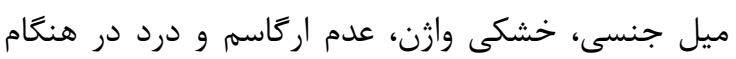
رابطهى جنسى مىباشد (11).

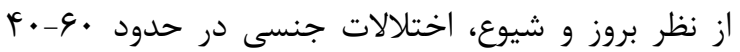

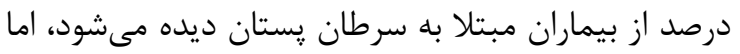

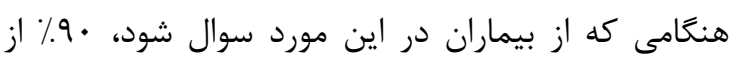

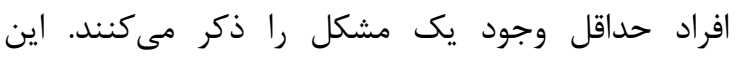

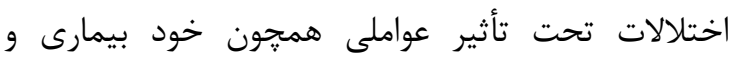

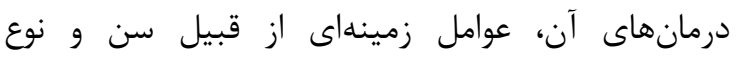

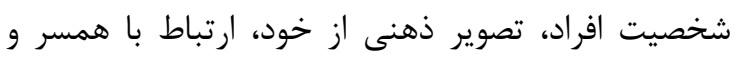

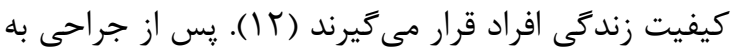

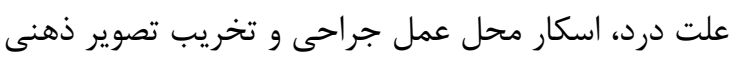

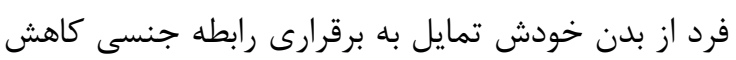

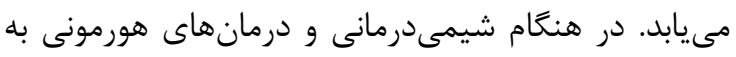

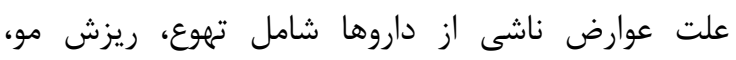

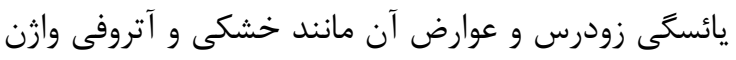

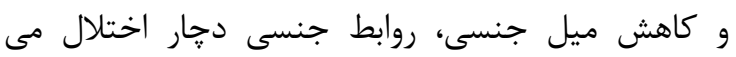

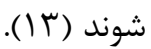

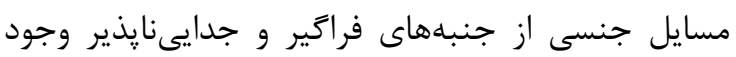

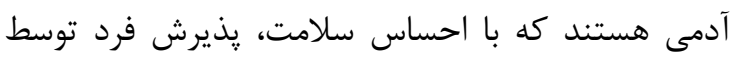
خود و تصوير ذهنى او از بدن خودش در رابطهى تنكَاتنَ آنى

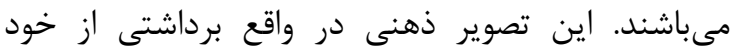

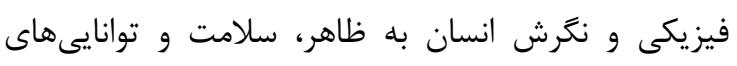

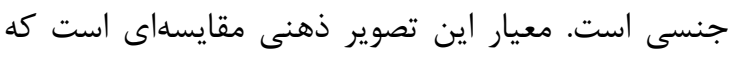

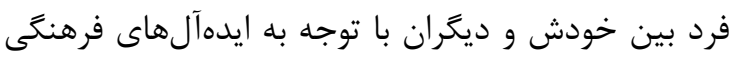

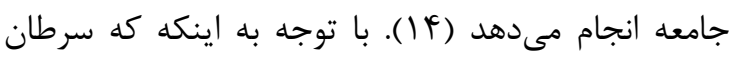

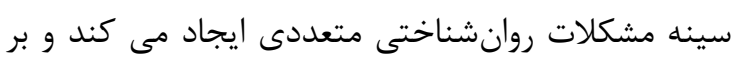

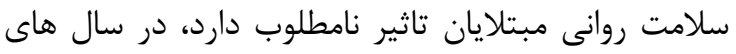

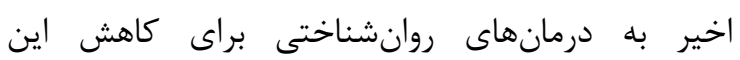

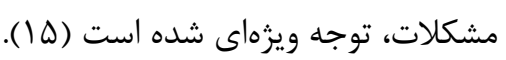

سرطان، از جمله بيمارىهاى مزمن و غيرواگيرى است كه كروه وسيعى از بيمارىها را شامل مى شود. اين بيمارى

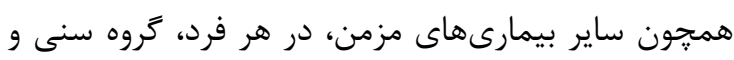

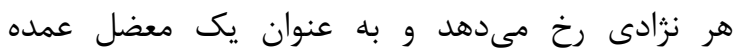

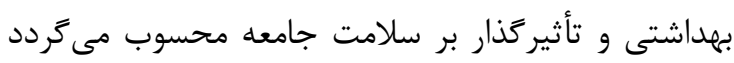

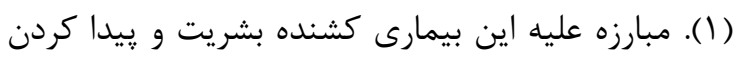

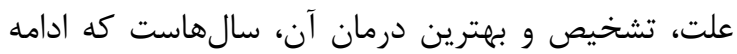
دارد (r). (1). بر اساس آخرين كزارش ثبت سرطان كشور در سال

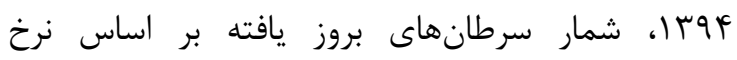

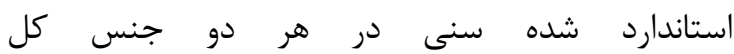

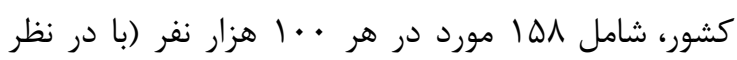

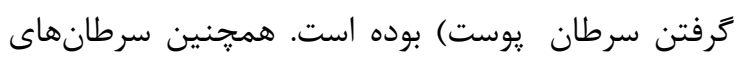

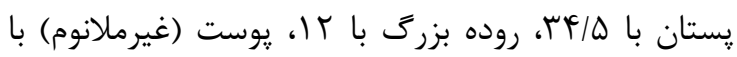

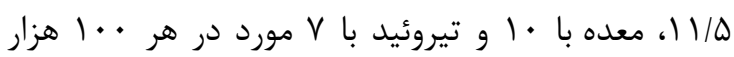

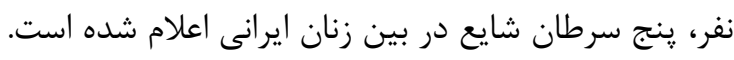

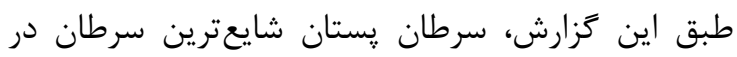

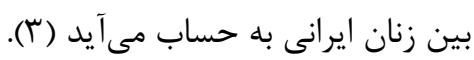

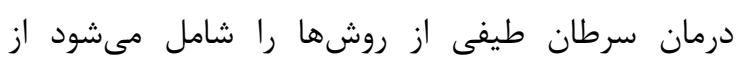

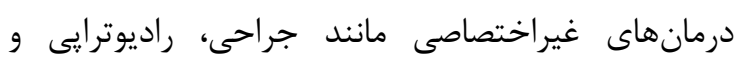

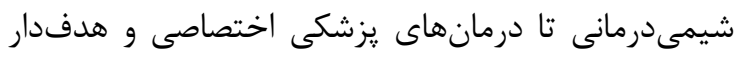

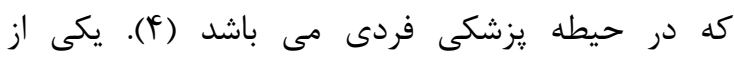

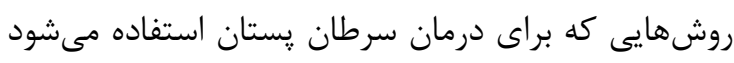

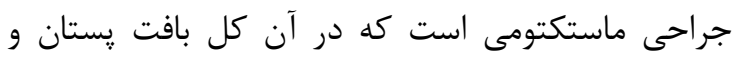
كاهى بافتهاى كنارى نيز برداشته مىشود (ه).

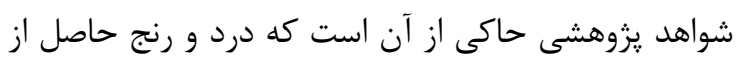

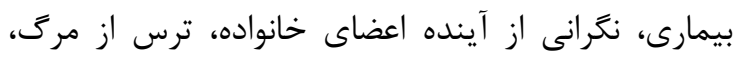

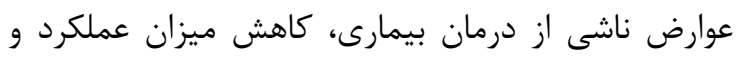

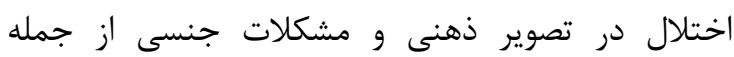
عواملى هستند كه سلامت روانى بيماران مبتلا به سرطان

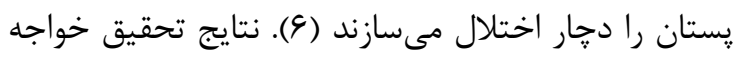

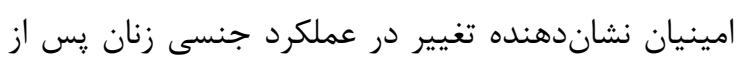

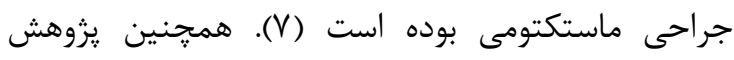

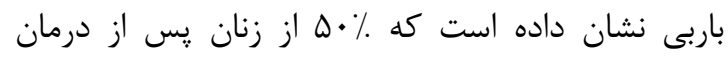

سرطان پستان، دجار مشكلات جنسى مى شوند (^).

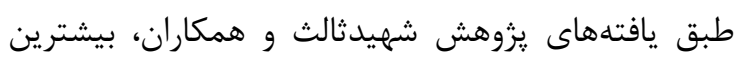

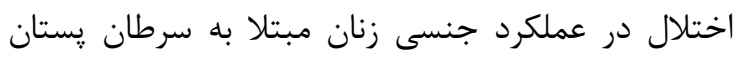

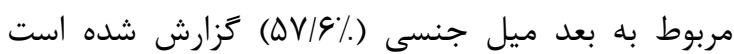


مبتنى بر يذيرش و تعهد است كه به صورت اكت

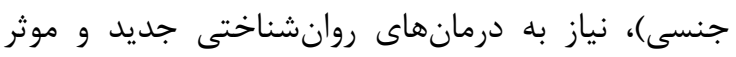

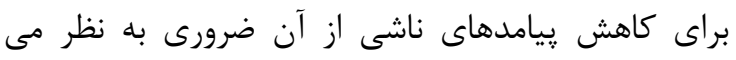

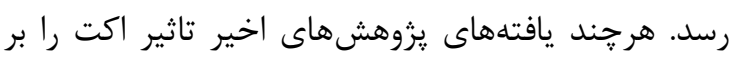

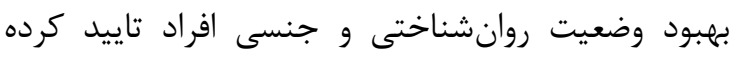

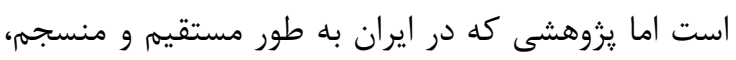

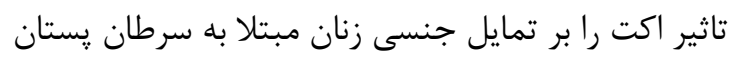

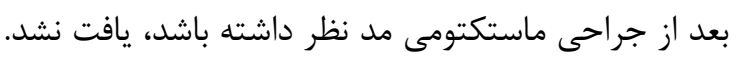

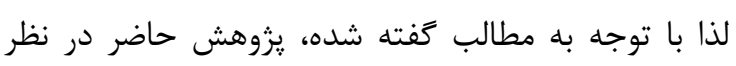

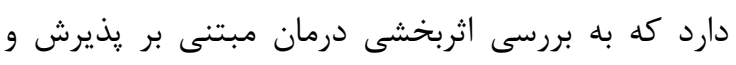

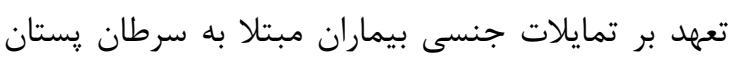

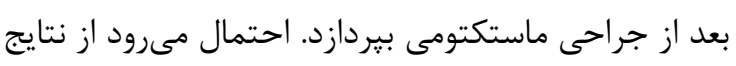

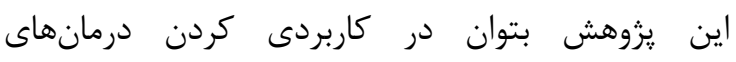

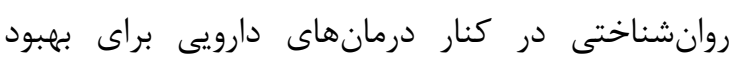

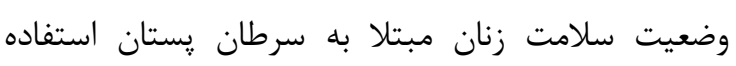

\section{مواد و روشها}

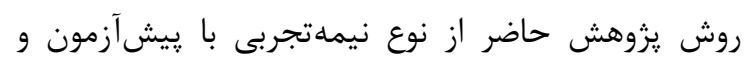

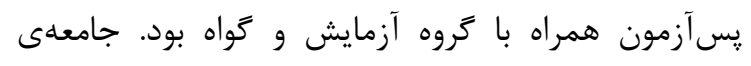

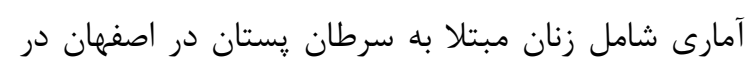

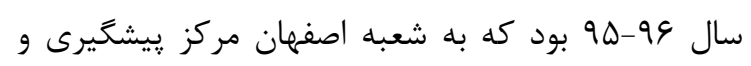

$$
\text { كنترل سرطان آلاء (مكسا) مراجعه كرده بودند. }
$$

در اين يزوهش براى محاسبه حجم نمونه و بررسى اندازه

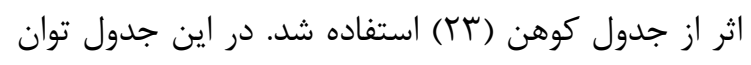

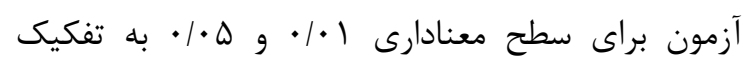

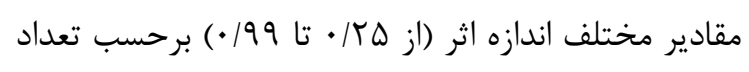

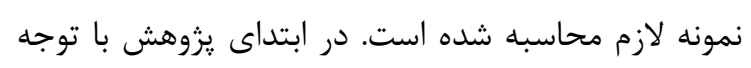

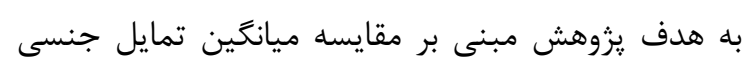

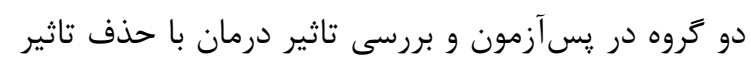

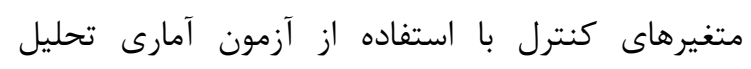

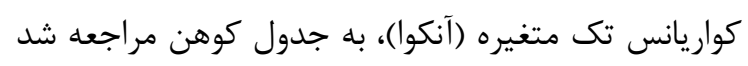

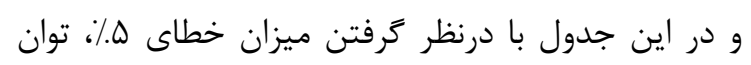

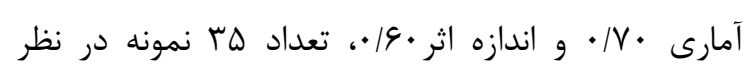

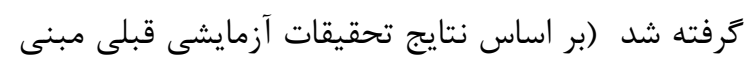

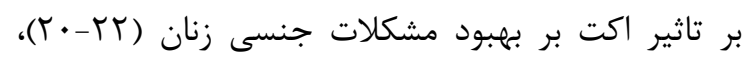
ميانگين اندازه اثر اين درمان حدود • ع٪ بوده است).

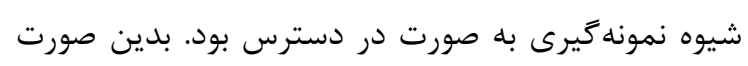

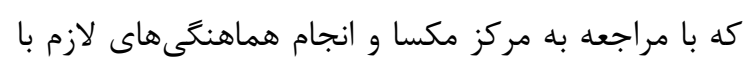

يكى از جديدترين و موثرترين اين نوع درمانها، درمان

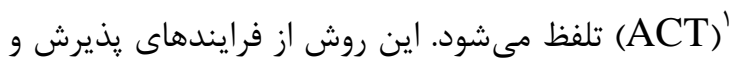

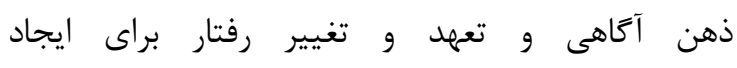
انعطاف ريذيرى روانشناختى استفاده مى كند يعنى رئى ايجاد

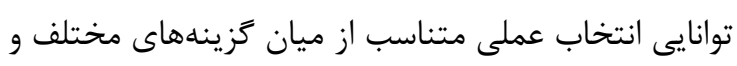

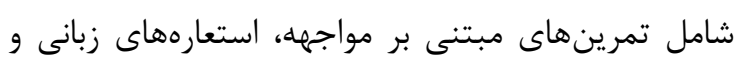

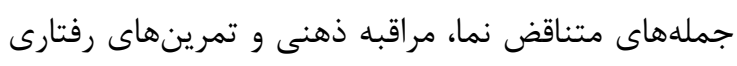
هدايت شده توسط ارزشها است. هدف اكت تغيير افكار و

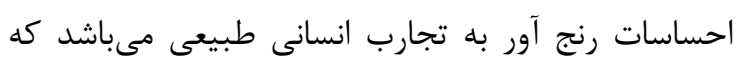

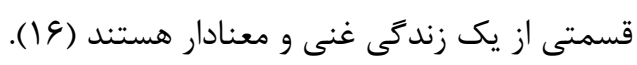

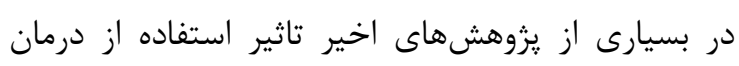

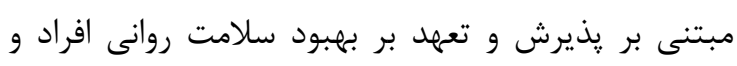

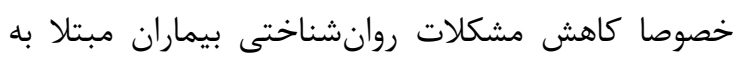

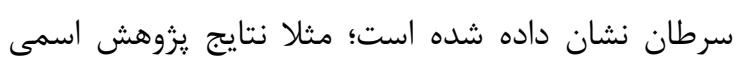

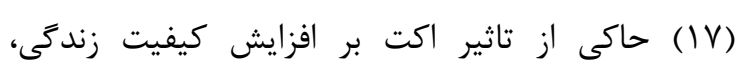

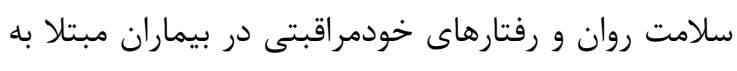

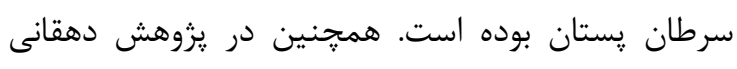

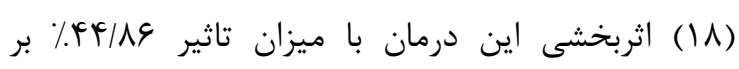

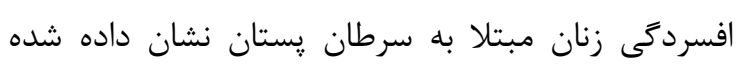
است. علاوه بر اين نتايج يزوهش عبدالهزاده و كبيرى نسب

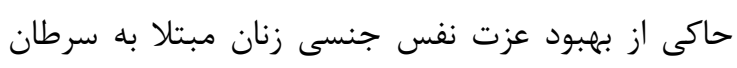

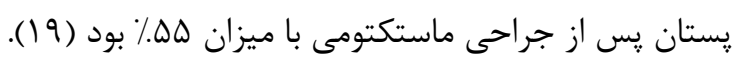

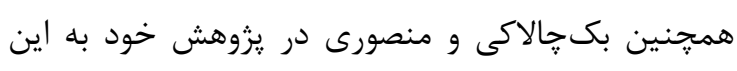

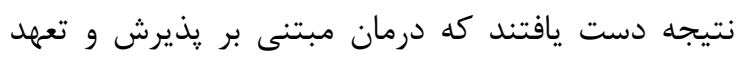

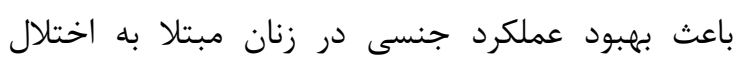

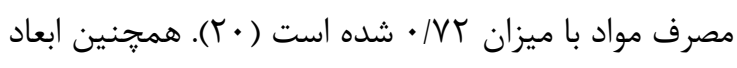
عملكرد جنسى شامل تمايل جنسى، برانكيختگى، اركاسه،

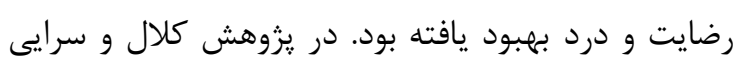

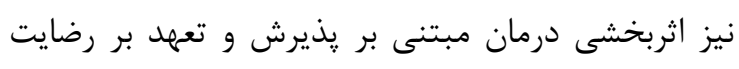

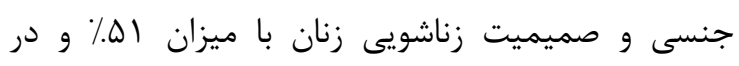
يزوهش طباطبايى و همكاران تاثير اين درمان با ميزان

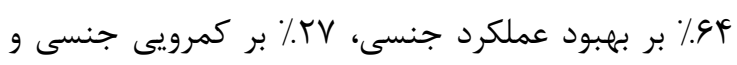

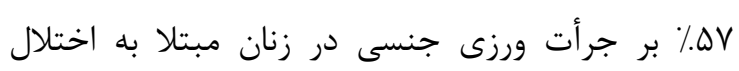
عملكرد جنسى نشان داده شده است (T T، آ (T).

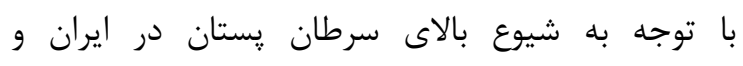

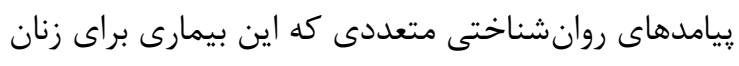

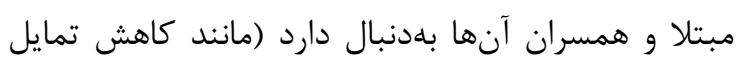

\footnotetext{
${ }^{1}$ Acceptance and Commitment Therapy
} 
مورد سنجش قرار مىدهد، بدين صورت كه هر آيتم به وسيلهى مقياس درجهبندى ليكرت با ه درجه نمره تذارى مىشود: •= هميشه קنين تمايلى دارم، ا= اكثرا جنين

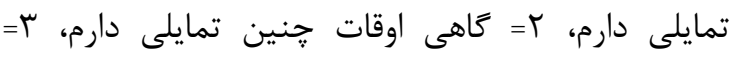

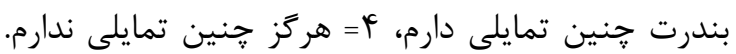

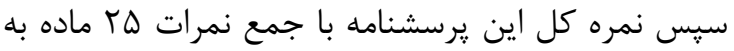

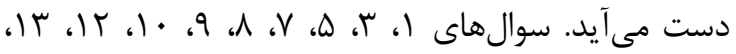

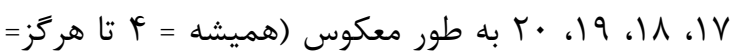
•) نمرهذذارى مىشود. حداقل نمره ممكن · و حداكثر

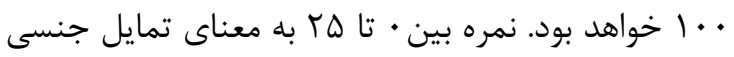

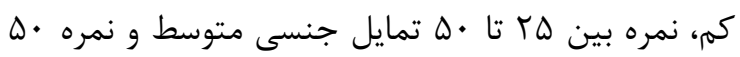

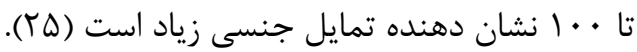

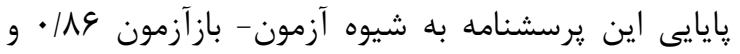

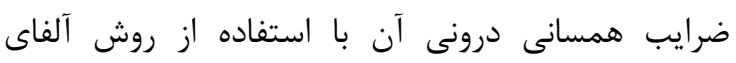

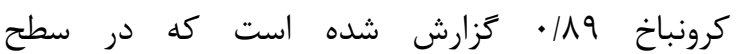
رضايتبخشى قرار دارند (؟)). خلاصه جلسات درمان بدين شرح بود: جلسه اول: توضيح جلسات درمانى، اهداف و سير درمان، تصريح نوع رابطه. جلسه دوم: سنجش عملكرد درماندگى خلاق و ارايه تكليف. جلسه سوم: معرفى دنياى درون و دنياى بيرون و

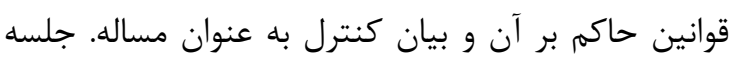

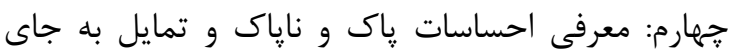

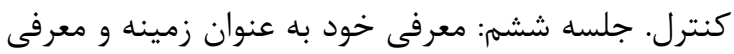

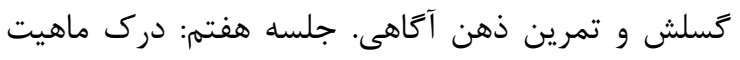

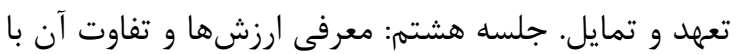

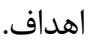
به منظور رعايت اصول اخلاقى، بيش از شروع كار رضايت

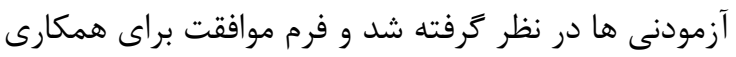
در يروهش توسط آنان تكميل شد و به آنان كفته شد كه

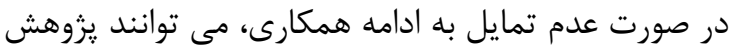

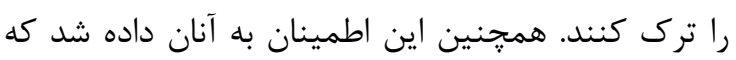
كليه مطالب ارائه شده در جلسات آموزشى و نتايج يرسشنامه محرمانه خواهد بود و نتايج در صورت تمايل براى آنها تفسير خواهد شد. ضمناً براى رعايت و و احتو احترام

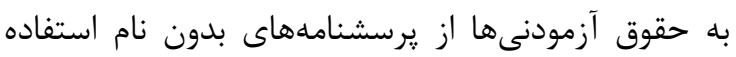
شد. همجنين مشاركت در اين تحقيق هيجَّونه بار مالى

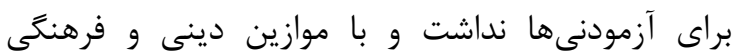
آزمودنى و جامعه نيز مغايرتى نداشت.
يزشكان متخصص مركز جهت ارجاع بيماران به يزوهشكر

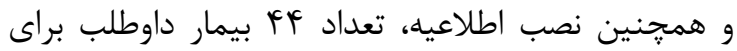
شركت در يزوهش اعلام آمادكى كردند.

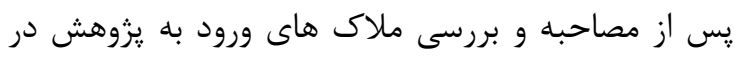
آنها، در نهايت تعداد Tس بيمار زن مبتلا بها مبه سرطان

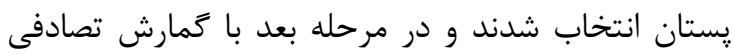

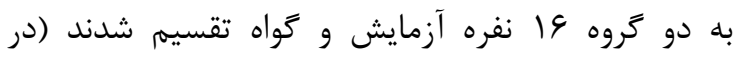
تحقيقات آزمايشى تعداد ها نفر براى هر كروه كافى است)

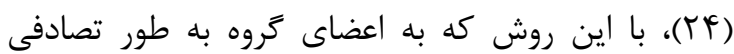

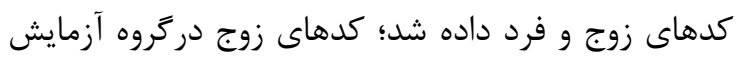

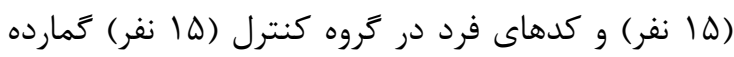
شدند. لازم به ذكر است كه بعد از ريزش، تعداد اعضاى هر كر كرد

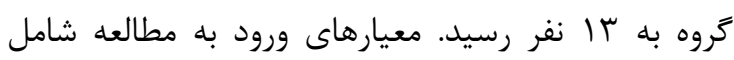

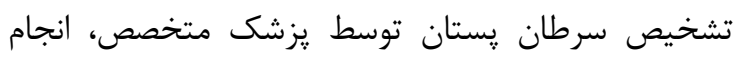

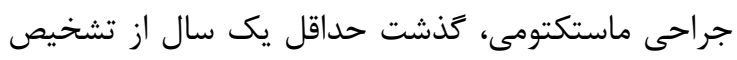
بيمارى، رضايت مراجع براى شركت در يروهش، متاهل

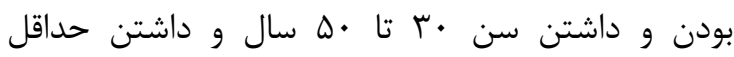
تحصيلات سيكل بود. معيارهاى خروج از يزوهش نيز شامل عدم همكارى مراجع

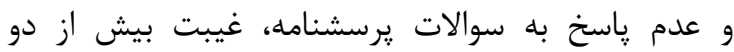

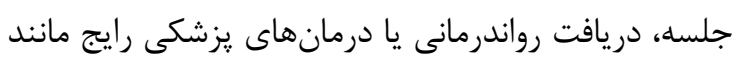

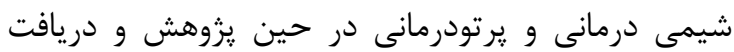

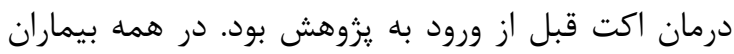

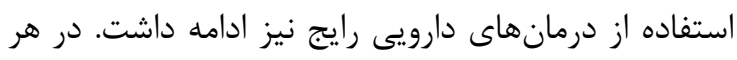
دو گروه يرسشنامه دمو گرافيك (سن، وضعيت تحصيلات، شغل، طول مدت بيمارى، فراوانى انواع درمانها) و وركات

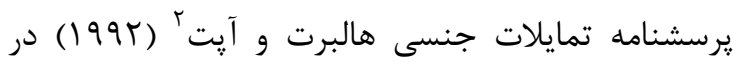

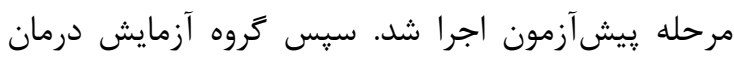

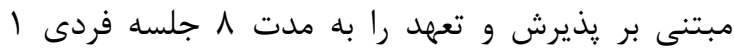

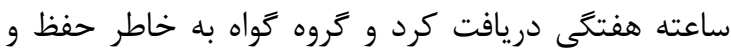

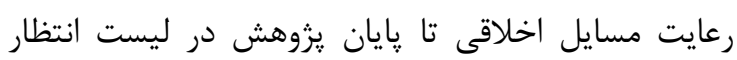

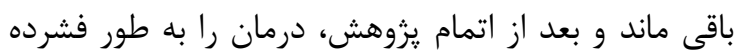

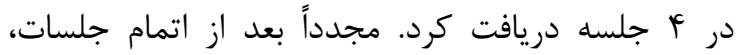

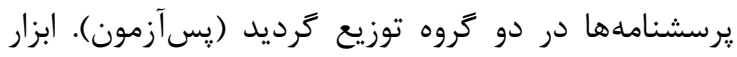

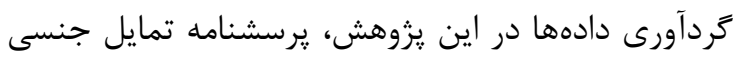
بود كه توسط هالبرت ساخته شده است.

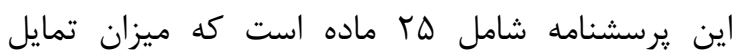

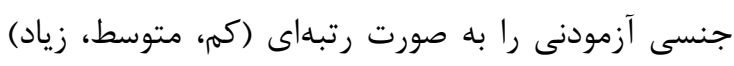

\footnotetext{
${ }^{2}$ Hurlbert \& Apat
} 


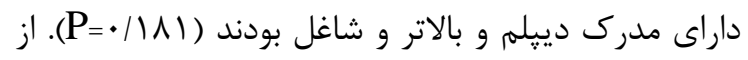

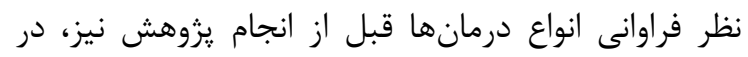

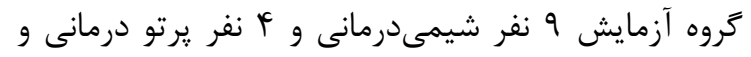

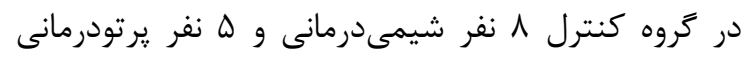

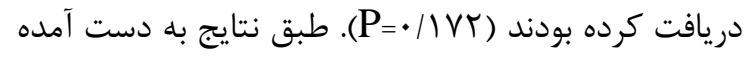

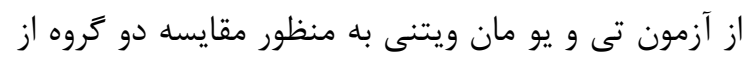

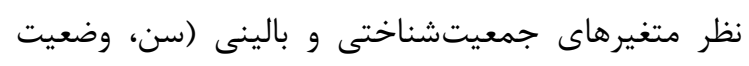

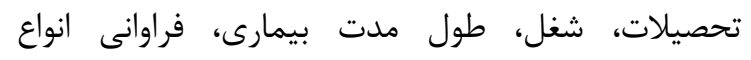

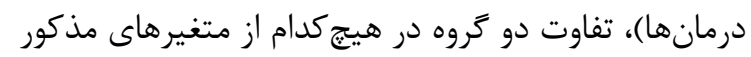
معنادار نبود (ه • P> P (P).

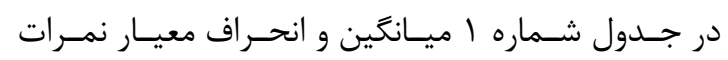

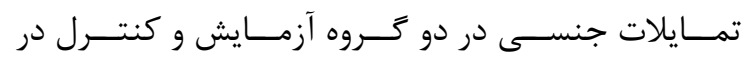
ريش آزمون و پِ يس آزمون آمده است.

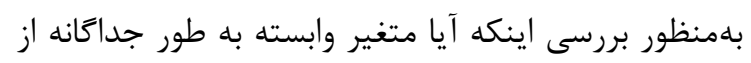

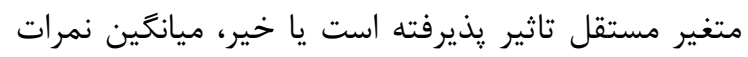

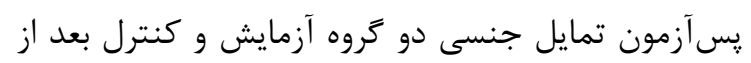

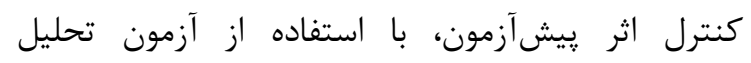

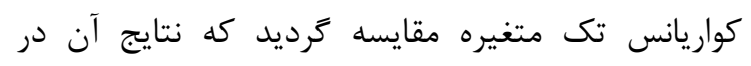
جدول شماره r ارايه شده است.

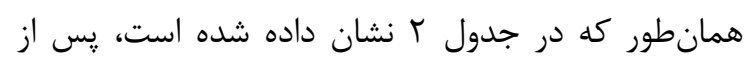

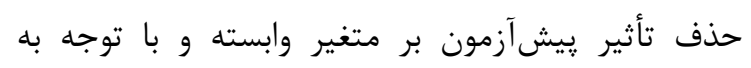

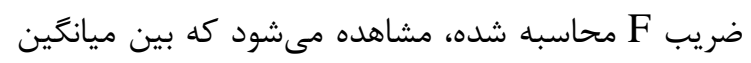

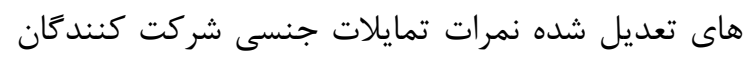

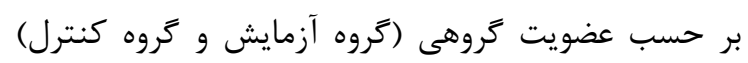

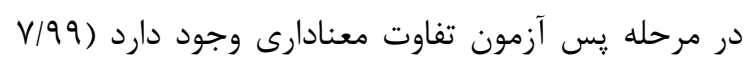

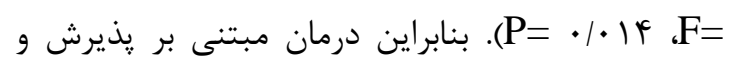

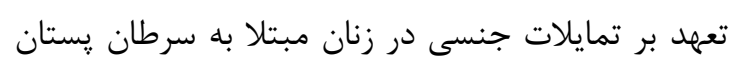

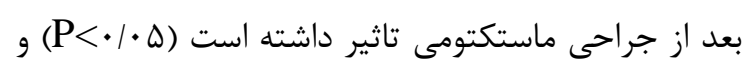

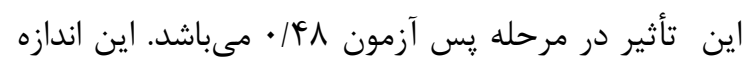

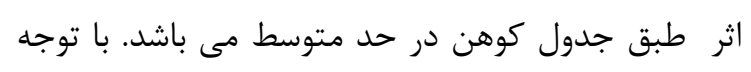

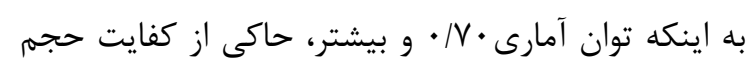

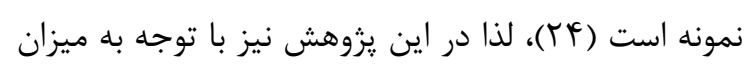

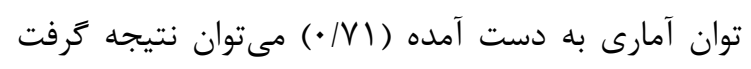

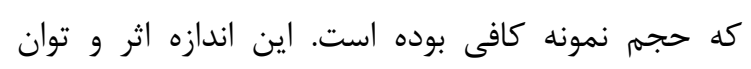

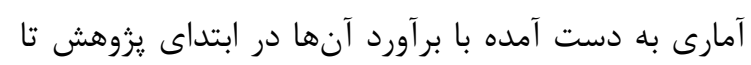
حد زيادى همخوان مىباشد.
در اين يزوهش دادههاى به دست آمده از يرسشنامه تمايل جنسى، به وسيله نرمافزار SPSS

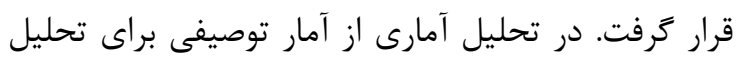

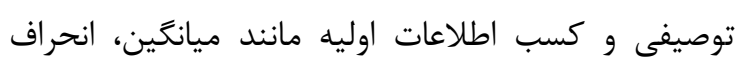

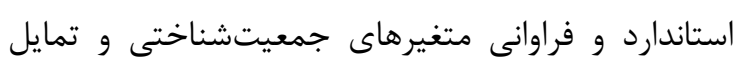

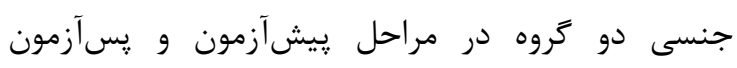

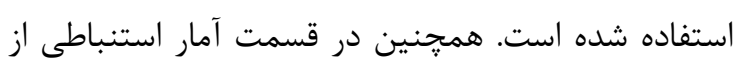

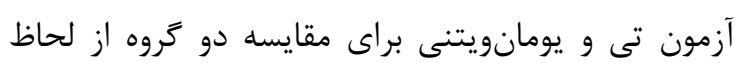

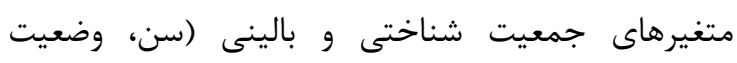

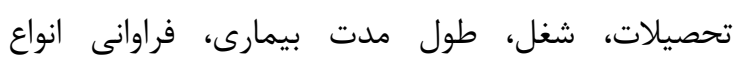

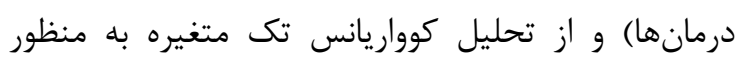
بررسى تاثير درمان و مقايسه ميانكين نمره تمايل جنسى كانى

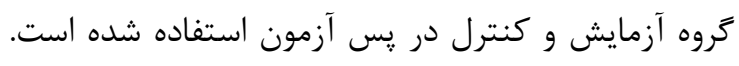

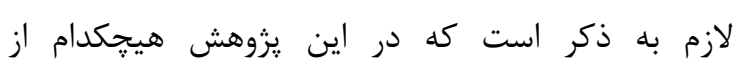

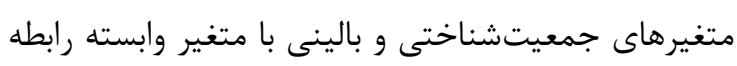

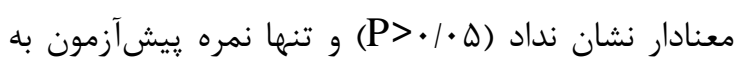

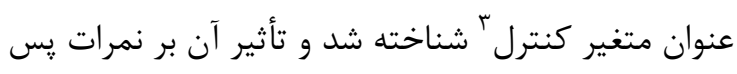

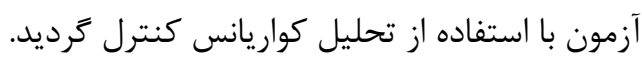

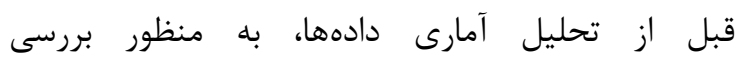
ييشفرضهاى تحليل كواريانس تك متغيرى از آزمون

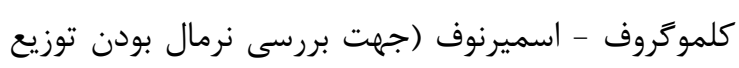

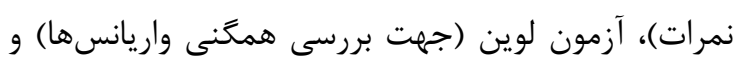

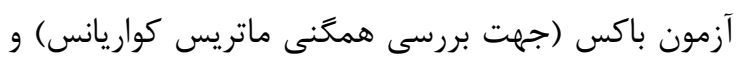

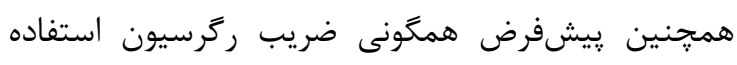

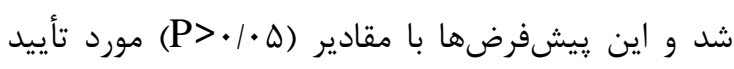
قرار گرفت؛ لذا مىتوان از تحليل كواريانس تك متغيرى

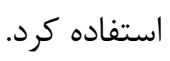

\section{يافتهها}

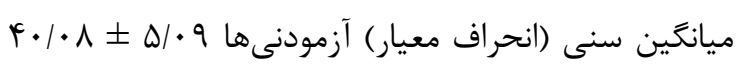
بود كه به تفكيك در كروه آزمايش كروه كنترل S/IV ميانگين و انحراف معيار طول مدت بيمارى (ماه) در كروه

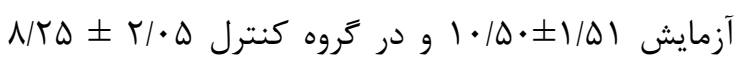

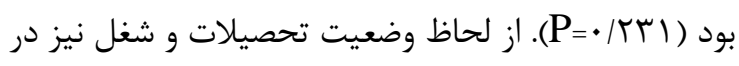

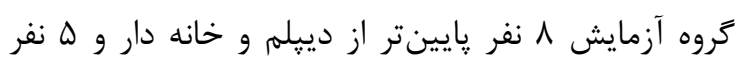

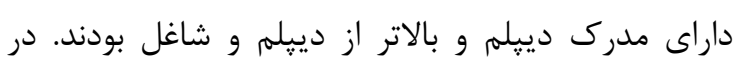

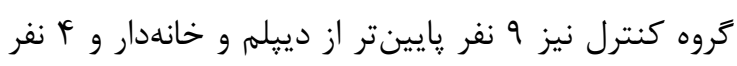

\footnotetext{
${ }^{3}$ control variable
} 


\begin{tabular}{|c|c|c|c|c|}
\hline سطح معنادارىp & ميانگين آزمون تمايلات جنسى (انحراف استاندارد) & ميانَّين آزمون تمايلات جنسى (انحراف استاندارد) & تعداد & تروه \\
\hline.$/ \cdot 14$ & $1 / T r(\cdot / T V)$ & $\cdot / \Lambda \Delta(\cdot / \mid \psi)$ & r & آزمايش \\
\hline.$/ 211$ & $1 / 19(\cdot / F T)$ & $I / / V(\cdot / \Delta \Delta)$ & זו & كنترل \\
\hline
\end{tabular}

جدول r: نتايج تحليل كواريانس تك متغيرى تمايلات جنسى در دو كروه آزمايش و كنترل در پِ آزمون

\begin{tabular}{|c|c|c|c|c|c|c|c|}
\hline توان آمارى & مجذور اتا & معنا دارى سطح & $\mathbf{F}$ & مجذانگين & آزادى درجه & مجذوروات & اثرات \\
\hline $1 / \cdot$ & $\cdot|N|$ &.$/ \cdots$ & $r r / \cdot 19$ & $1 / 49 V$ & 1 & $1 / r 9 V$ & يِيش آزمون \\
\hline \multirow[t]{2}{*}{$\cdot|V|$} & $\cdot / 4 \wedge$ & $.1 \cdot 1 \mathrm{~F}$ & V/99r & $\cdot|r| F$ & 1 & . MIF & عضويت گروه \\
\hline & & & & . & rו & $\cdot \mid 011$ & خطا \\
\hline
\end{tabular}

و بقيه بيماران داراى مدرك دييلم و بالاتر و شاغل بودند.

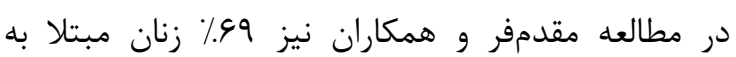

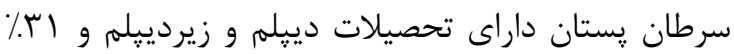

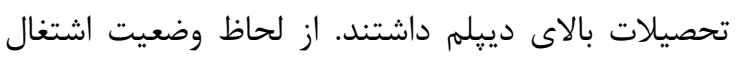

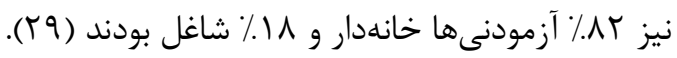

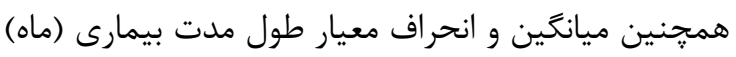

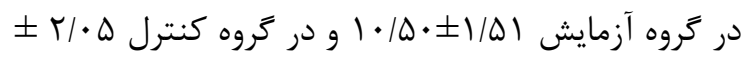

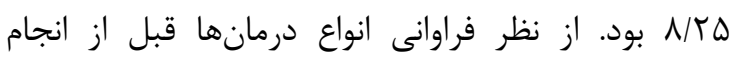

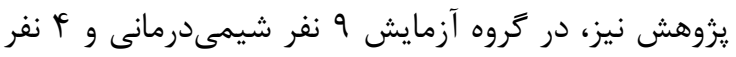

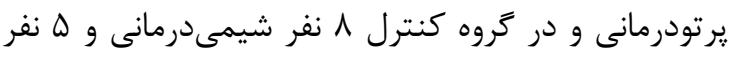

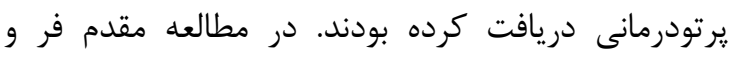

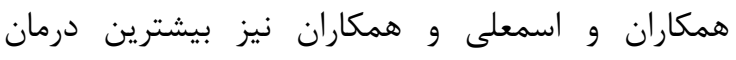

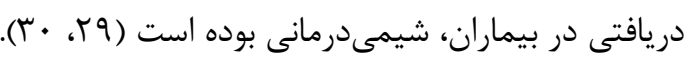

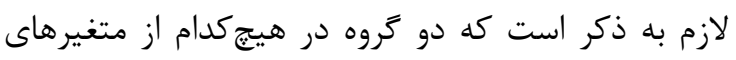

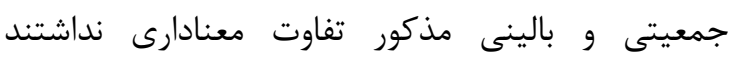
(P> (P> (P)، لذا با اطمينان بيشترى مى توان در مورد تاثير

$$
\text { درمان بر تمايل جنسى اظهار نظر كرد. }
$$

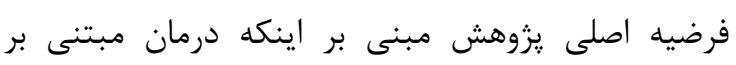

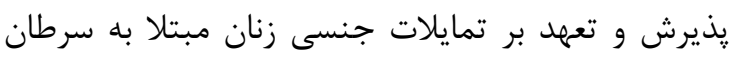

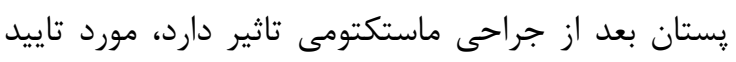

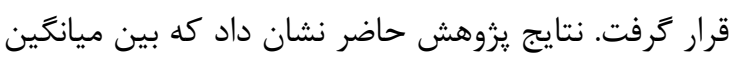

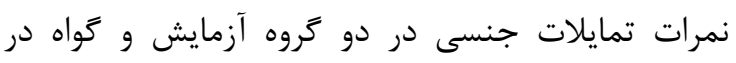

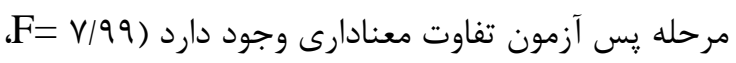

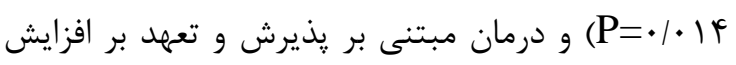

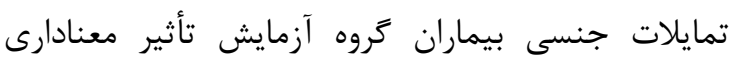

\section{بحث} هدف يزوهش حاضر بررسى اثربخشى درمان مبتنى بر

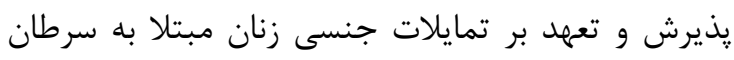

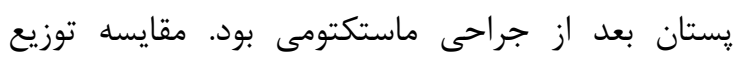

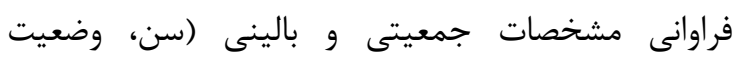

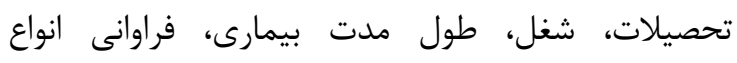

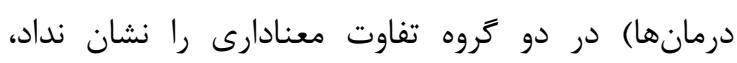

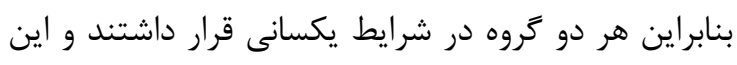

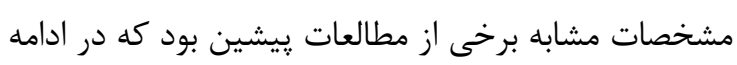
به برخى از آنها اشاره مىشود.

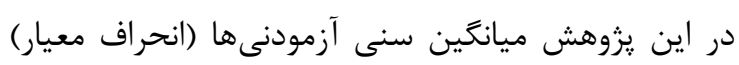

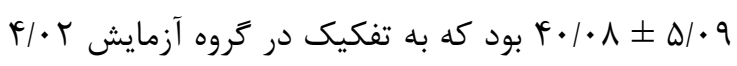

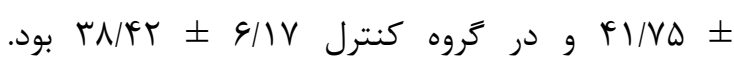
يزوهشهاى موجود نشان مىدهد كه در ايران ميانكين

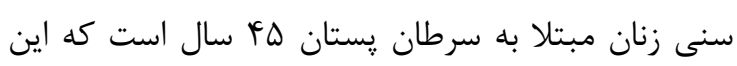

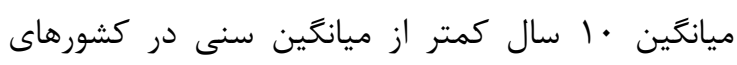

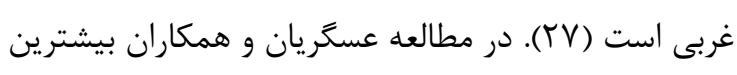

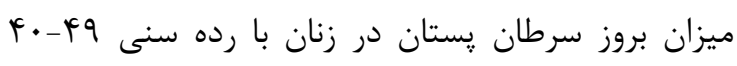

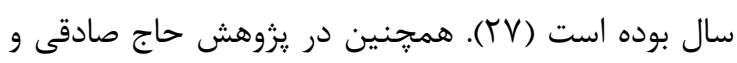

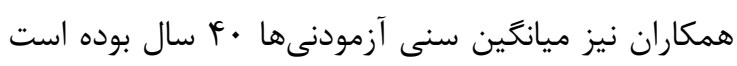

بيشتر افراد شركت كننده در يزوهش حاضر از لحاظ

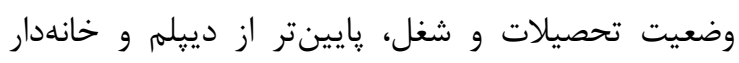

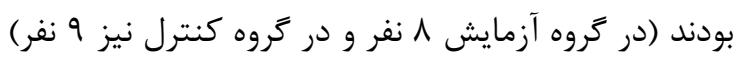




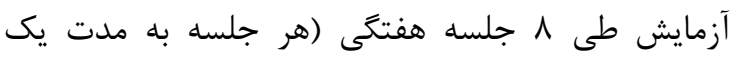
ساعت)، اكت را دريافت كردند. نتايج يزوهش آنها حاكى جانى از بهبود عزت نفس جنسى زنان مبتلا به سرطان برانتان إنان

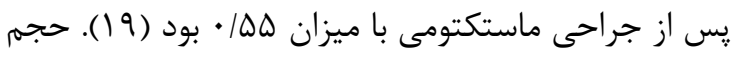

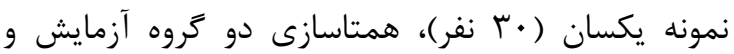
كنترل و تخصيص تصادفى بيماران به دو كروه، نمونه

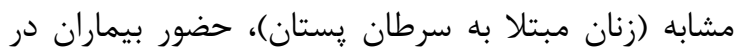

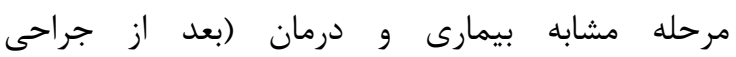
ماستكتومى)، استفاده از روش درمانى و تكنيكهاى يكسان در طول جلسات درمان (اكت)، تعداد جلسات

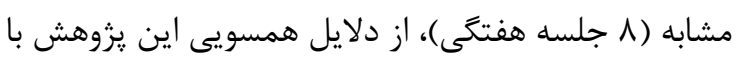
نتايج يزوهش حاضر مى باشد.

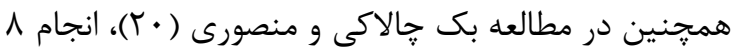

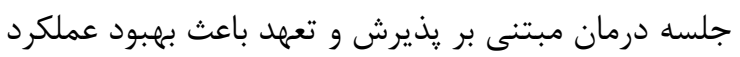

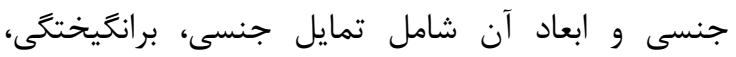

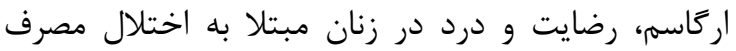

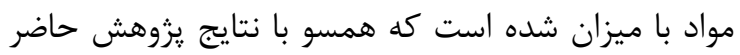

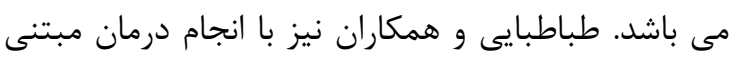
بر يذيرش و تعهل، بهبود عملكرد جنسى، كم رويى جنسى

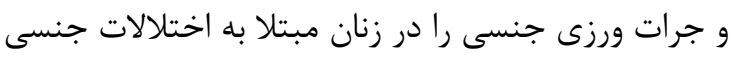

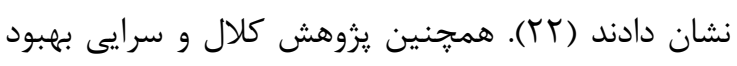

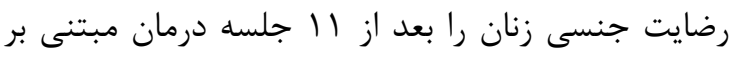

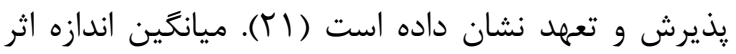

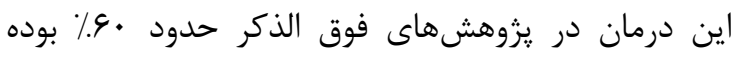

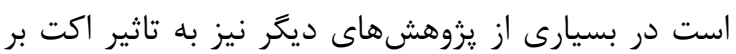
بهبود مشكلات جنسى زنان مانند افزايش رضايت زناشويى ينائ

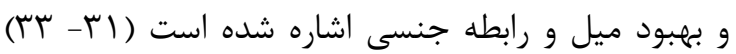

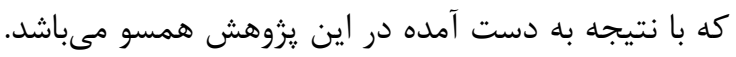

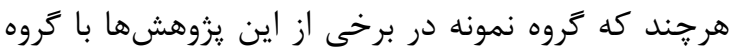

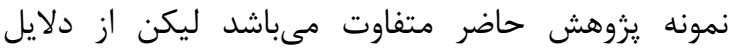

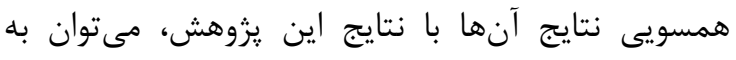
جنسيت كروه نمونه (زنان)، حجم نمونه مشابه، استفاده از إن إنان يروتكل درمانى مشابه و انتخاب متغير وابسته مشابه

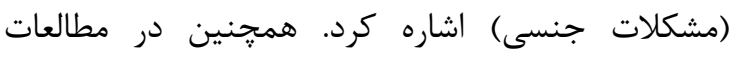

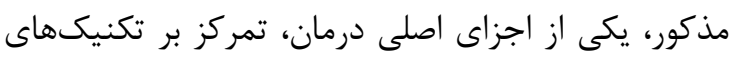

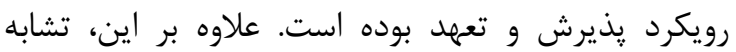
برخى از مشخصات جمعيتى و بالينى در اين تحقيقات

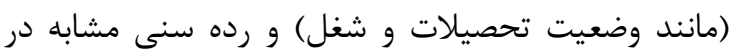

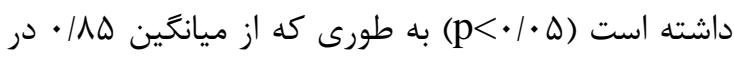

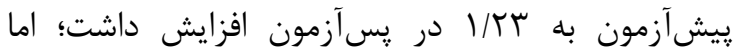

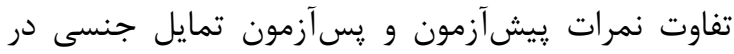

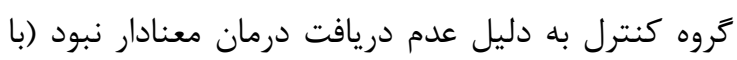

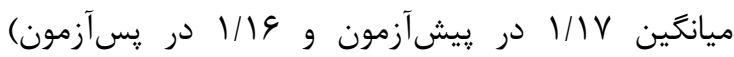
.$(\mathrm{P}>\cdot / \cdot \Delta)$ ميزان تاثير درمان در مرحله يس آزمون

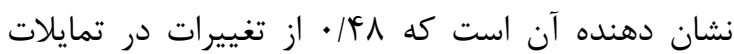

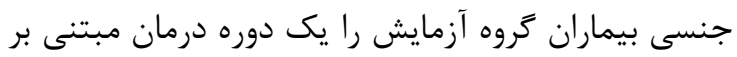

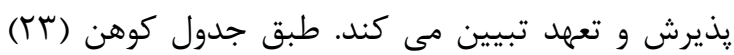

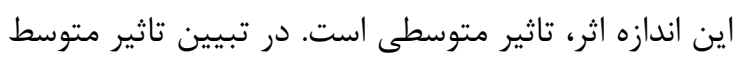

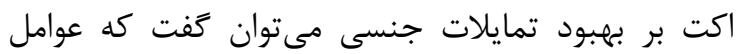
زيادى از قبيل جسمى، روانى و اجتماعى بر تمايلات

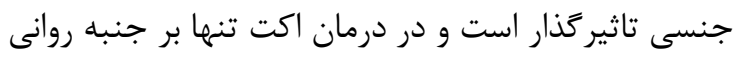
مشكلات تاكيد مىشود، بنابراين بهتر است از اين درمان دان دان در كنار ديخر درمانهاى يزشكى براى مبتلايان به سرطان

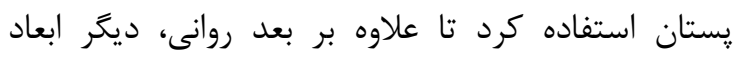

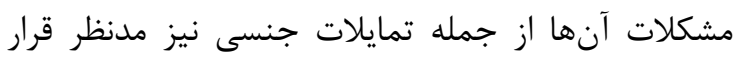
بخيرد. همجنين در اين يروهش به دليل شرايط سخت

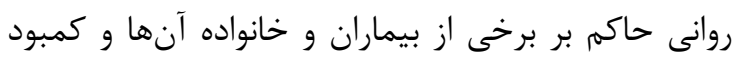

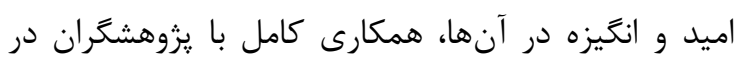

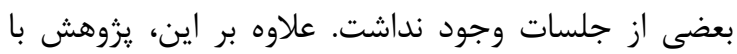
ريزش تعدادى از اعضا و در نتيجه كاهش حجم نمونه

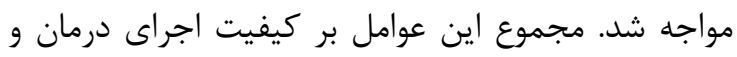
كاهش ميزان تاثير آن، اثركذار بوده است.

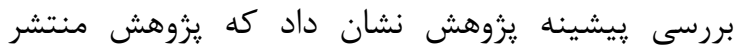

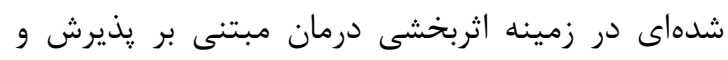

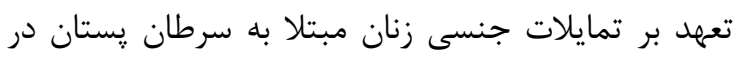

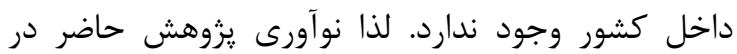

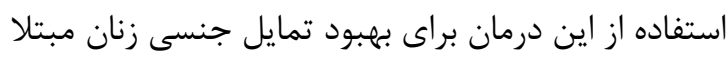
به سرطان يستان بعد از جراحى ماستكتومى بوده است.

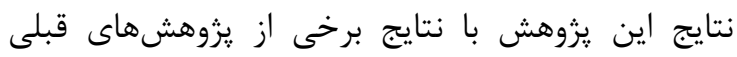
مبنى بر تاثير اكت بر بهبود مشكلات جنسى زنان بنان همخوان

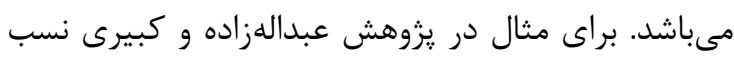

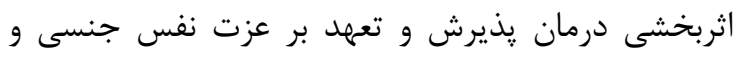

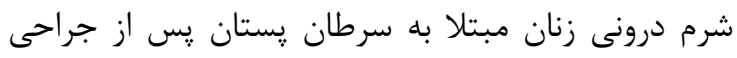

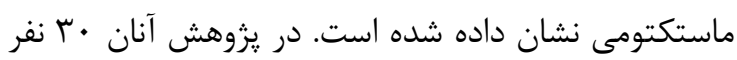

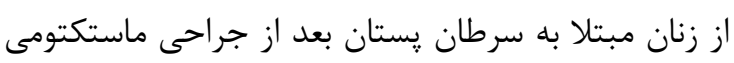

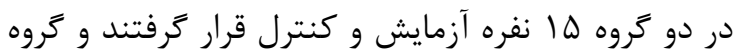


ممكن است واقعيت نداشته باشد و واسخ دادن او به اين

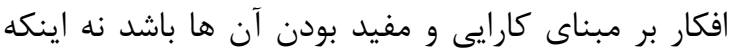

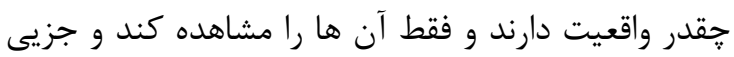

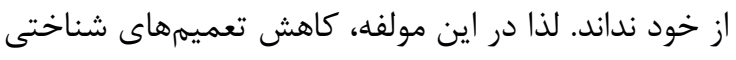
افراطى بيمار و كاهش اضطراب و افسردىى ناشى از آنها

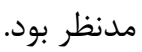
همجنين در اين يزوهش در مقابل اجتناب، به بيمار

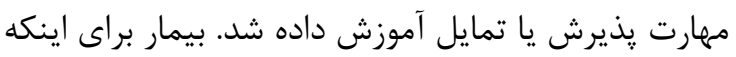
احساسات و افكارى مانند 》ابدشكلى بدن" يا يات النداشتن

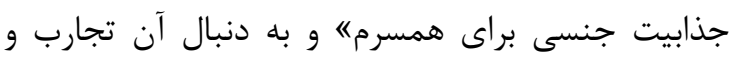

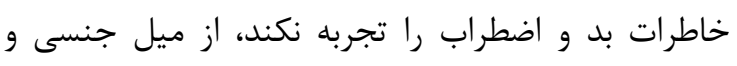

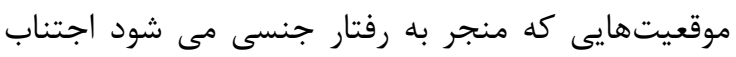
مى كند و اين يك رفتار مقابلهاى محسوب مىشود كهد خهو

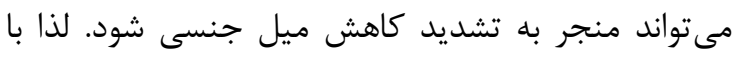
كمك روشهاى اكت به بيمار آموخته شد كه به به جائ جاى

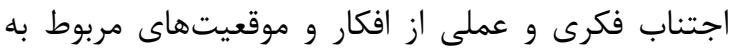

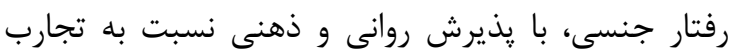
درونى مربوط به عمل جنسى مانند افكار يا احساسات

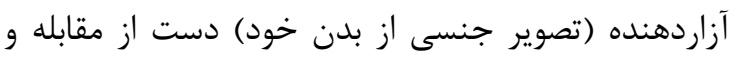

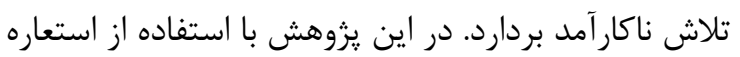

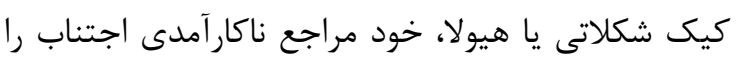

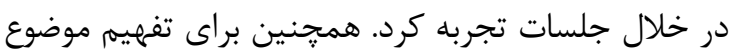
يذيرش و اجتناب از استعارههاى اتوبوس و مهمان ناخوانده

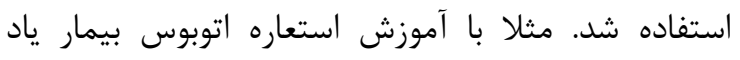

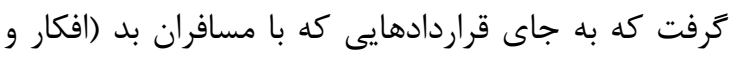

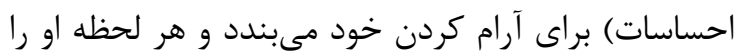

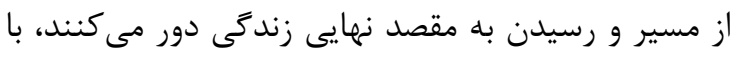

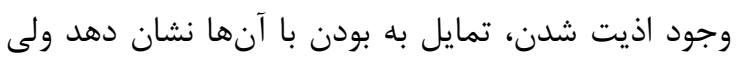
در نهايت در مسير ارزشهايش قرار كيرد. مثلا در اين

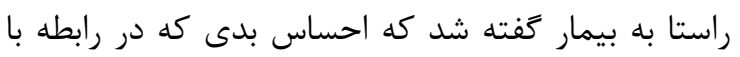

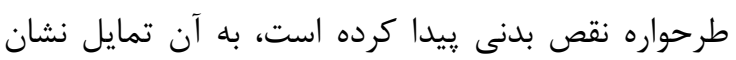

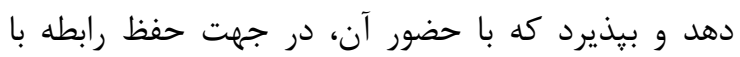

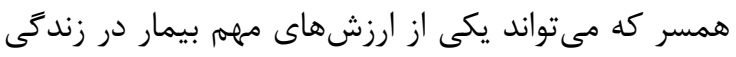

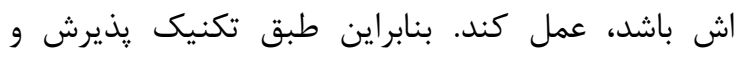

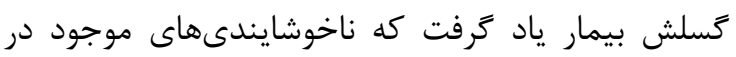
ديكر زمينهها را وارد حوزه جنسى و زناشويى نكند و آن را كان همان كونه كه هست بيذيرد.

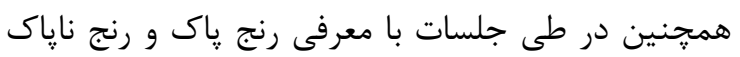
به بيمار آموزش داده شد كه خيلى از احساسات و افكار
آزمودنىها (•(--r سال) احتمالا بر همخوانى نتايج تاثير خذار بوده است. با توجه به يافتههاى اين يزوهش، در تبيين اثربخشى اكت

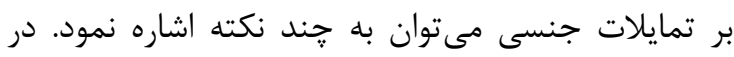
اين درمان با مولفههايى همجيون يذيرش، كسلش، تمركز

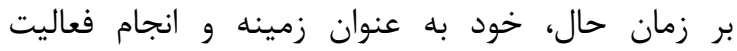

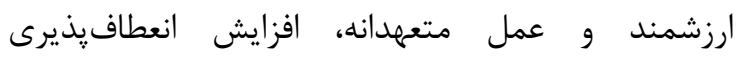
روانشناختى، بهبود باورها و رفتارهاى منفى و غيرقابل انعطاف، ترميم احساس ارزشمندى، بهبود سطح خلق و به به

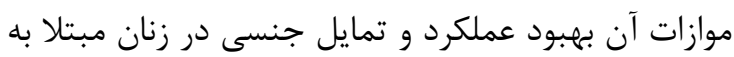

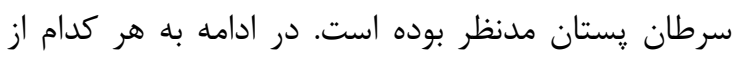

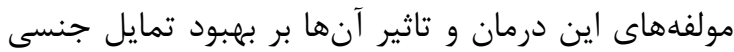

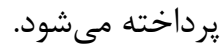
بعد از جراحى ماستكتومى به علت ايجاد نقص بدنى بنى، بيمار

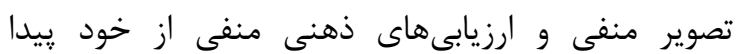

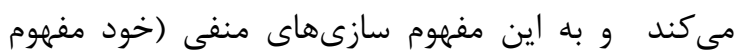

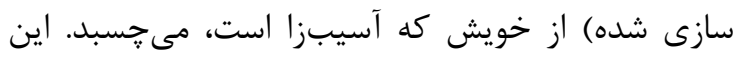

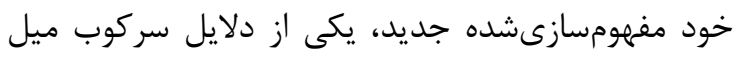
جنسى و اجتناب از برقرارى رابطه جنسى مى باشد. در اين

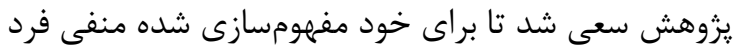

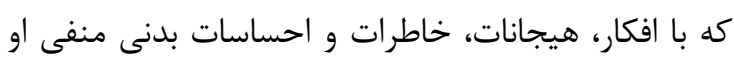
تعريف مىشود، جايكزين ييدا شود. لذا تاكيد بر تغيير نكاه از خود مفهومسازىشده (مثلا خود قربانى يا خود ناقص)

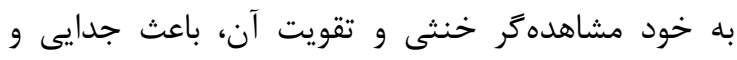

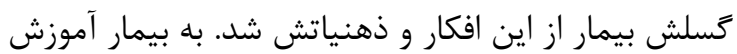

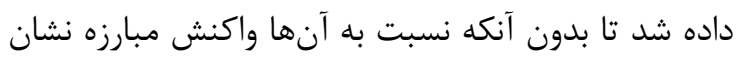

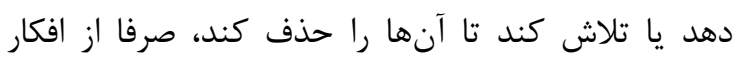

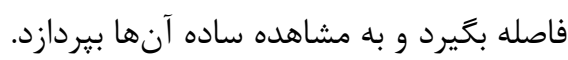
در واقع با كمك روش جايكزين كردن خود به عنوان

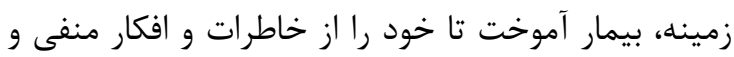

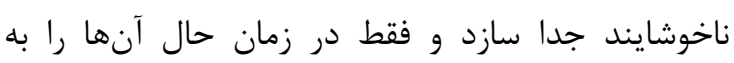
سادگى تجربه نمايد. بدين منظور با كمك استعاره شطرنج از فرد خواسته شد تا خود را مانند صفحه شطرنج و وافكار باري خوب و بد را همجيون مهرههاى سياه و سفيد شطرنج درد درد

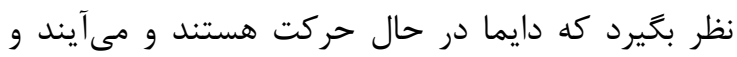

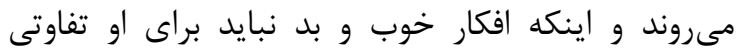

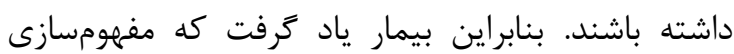

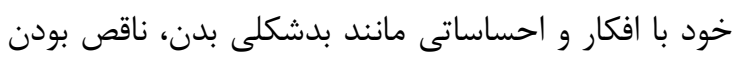
و كاهش جذابيت جنسى، بيشتر توليد ذهن خود اوست و 
ارزشهايشان را گم كرده باشند. قرار كرفتن در راستاى

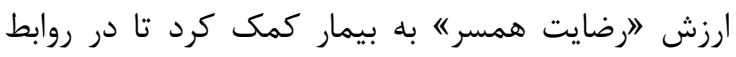

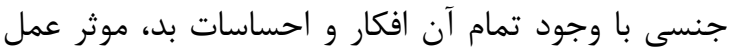

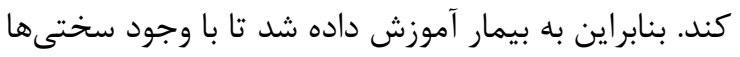

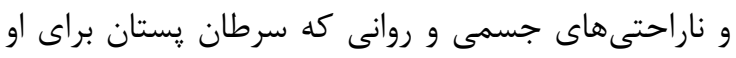

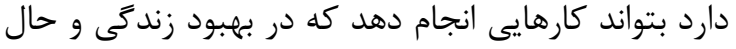

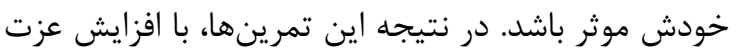

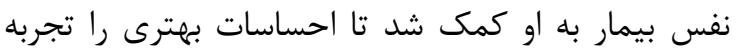

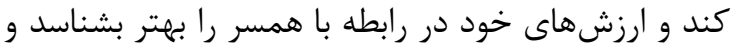

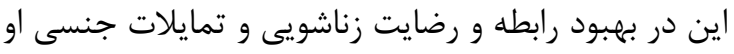

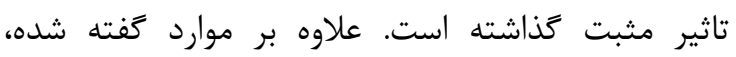
بخشى از آموزشها در طى جلسات بر تكنيكهاى ذهن آنس

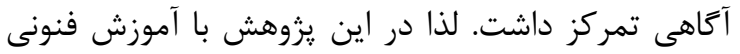

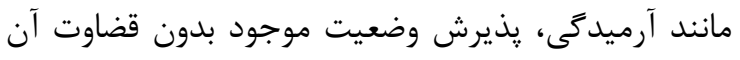
و هشيار بودن نسبت به خويش، هشيارى نسبت به لحظه

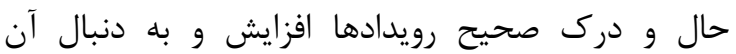

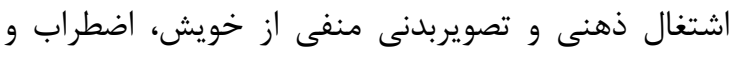
افسردگى كاهش يافته است و همين نتيجه نيز توانسته است به افزايش تمايل جنسى بيماران كمك نمايد.

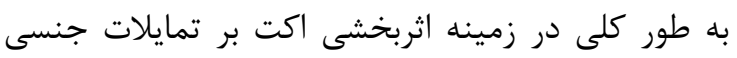

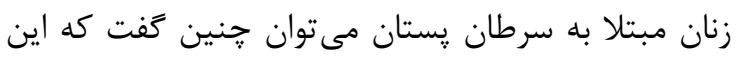

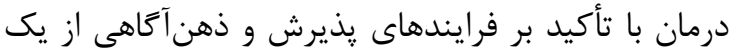
سو و فرايندهاى تعهد و تغيير رفتار از سوى ديكر باعث

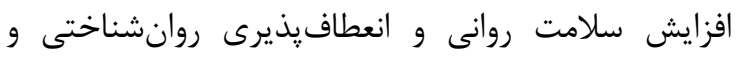
همجنين بهبود تمايلات جنسى بيماران شده است. در اين

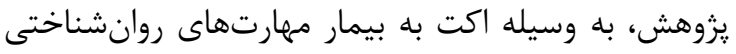

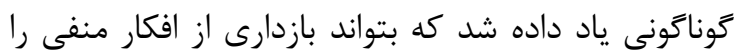

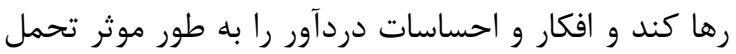

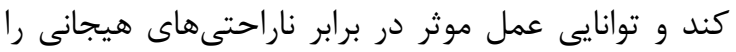

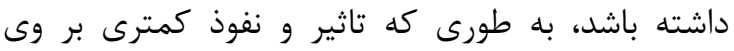

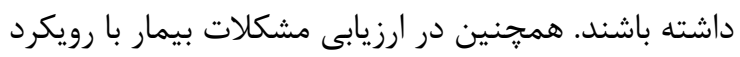

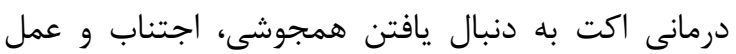
ناكار آمد در بيمار بوده و با تصريح ارزشها و تعيين اهداف باف

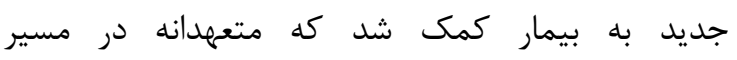
ارزشهايش بماند، بهجاى همجوشى با افكار مزاحم از تكنيكهاى كسلش و در مقابل اجتناب بيمار از افكار و احساسات، علايم بدنى، خاطرات و اميال آزار دهنده،

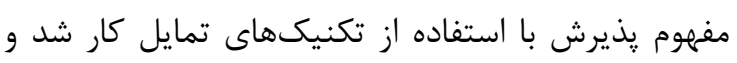

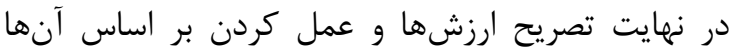

بدى كه به دنبال جراحى ماستكتومى به وجود آمده بودند را فقط يك فكر تجربه كند و به جاى ياسخ به آنها، به به بهاس انجام آنجه در زندگى برايش مههم و در راستاى ارزشهايش

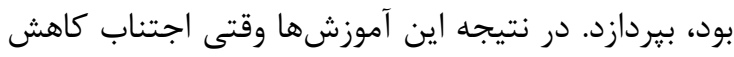

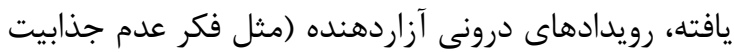
جسمى) براى بيمار كمتر تهديد كننده و بيشتر قابل

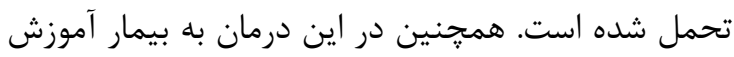

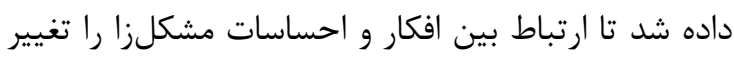
دهد و آنها را به عنوان علايم مرضى در نظر نغيرد بلكه

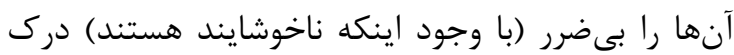

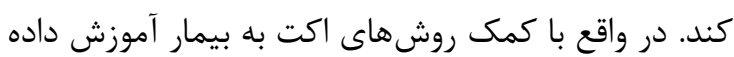

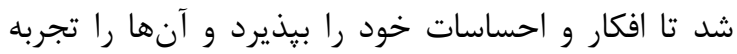

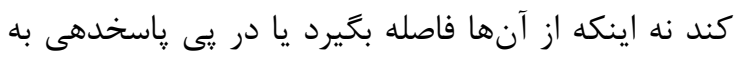

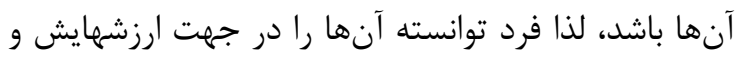
نيز فعاليتهاى هدفمند به كار كيرد. در اين جا بيماران

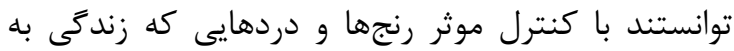

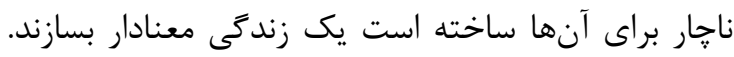

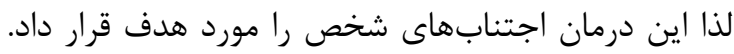

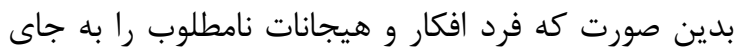

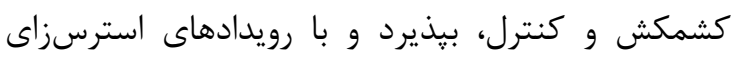

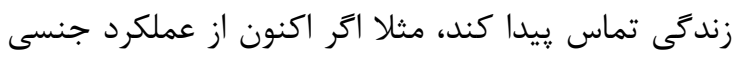

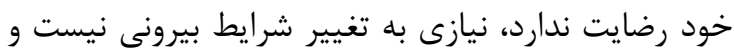
حتى در همين شرايط و بدون تاثير يذيرفتن از آن همم مى نى ني

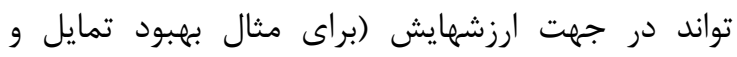
عملكرد جنسى) كام بردارد. همانطور كه اشاره شد، در اين درمان بر افزايش فعاليتهاى ارزشمند (مانند بهبود روابط بين فردى، دران

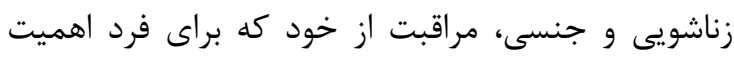

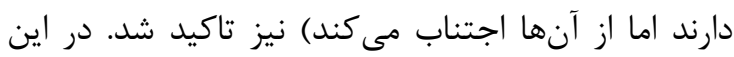
يزوهش براى رسيدن به اين هدف، شناسايى اين ارزشها

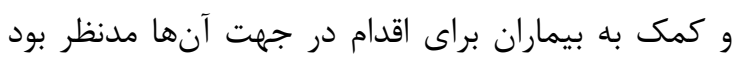
كه بر اساس آن با استفاده از كاربرك التعيين اهداف مبتنى بر ارزشهاه به بيمار كمك شد تا در سه مرحله

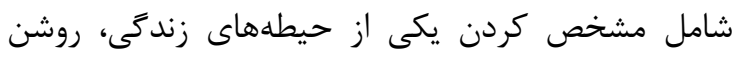

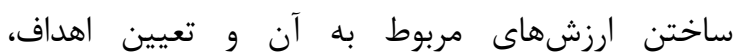
مهارتهاى لازم براى زندگى ارزشمند را كسب كند. مثلا

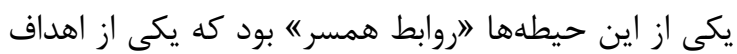

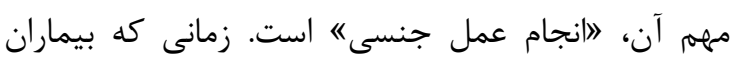
تمايلى براى رفتار جنسى ندارند، در واقع ممكن است است استى 
اين روش با اطمينان بيشترى برآورده شود. همجٍنين انجام تحقيقات وسيعتر و با شرايط دقيقتر در اين زمينه مىتواند راهكارهاى كاربردىترى از اين مداخله را در سيستمهاى بهداشتى و درمانى روشن نمايد و در صورت اثبات اثربخش بودن اين درمان، برنامهريزى لازم جهرت لحاظ نمودن آن در جارجوب آموزشى و درمانى درنى مراكز مرتبط با بيمارى سرطان در نظر كرفته شود.

\section{نتيجهكيرى}

به طور كلى نتايج يزوهش حاضر نشان داد كه درمان مبتنى بر يذيرش و تعهد بر افزايش تمايلات جنسى زنان ئن مبتلا به سرطان يستان بعد از جراحى ماستكتومى موثر

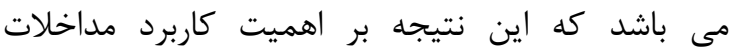
روانشناختى در فرايند درمان مبتلايان به سرطان يستان

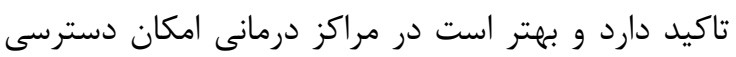

$$
\text { به آنها فراهم كردد. }
$$

\section{تشكر و قدردانى}

در گايان از مساعدتهاى تمامى عوامل به ويزه مسؤلين محترم شعبه اصفهان مركز ييشخيرى و كنترل سرطان

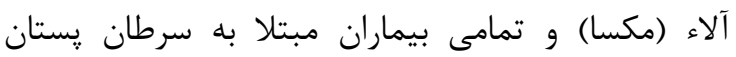

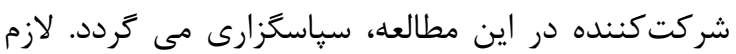
به ذكر است كه يزوهش حاضر حاصل پايان نامه كارشناسى ارشد دانشگاه آزاد اسلامى نجف آباد با باد كد مصوب .

\section{تعارض منافع}

نويسند Fان اعلام مى دارند كه هيج تعارض منافعى در

$$
\text { يزوهش حاضر وجود ندارد. }
$$

\section{References}

1. Siegel R, Ward E, Brawley O, Jemal A. The impact of eliminating socioeconomic and racial disparities on premature cancer deaths. CA Cancer J Clin. 2011; 61 (4): 212-36.

2. Sabatino SA, Lawrence B, Elder R, Mercer SL, Wilson KM, DeVinney B, et al. Effectiveness of
براى بيمار، منجر به تاثير درمان شده است. در مجموع،

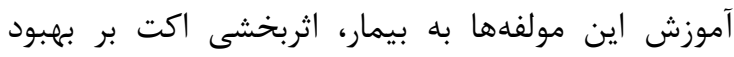

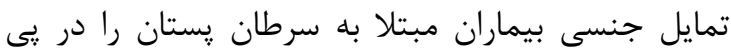

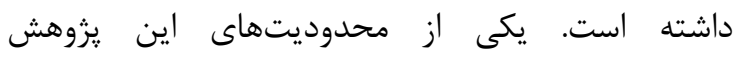
به كارگيرى روش نمونه گيرى در دسترس بود. همجنين به إنه

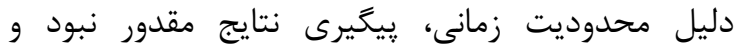
اطلاعاتى در مورد تداوم بهبودى درمان در دسترس نيست. علاوه بر اين، در اين يزوهش به بررسى اثربخشى درمان

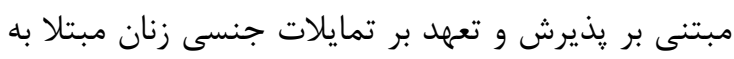
سرطان گِستان اصفهان يرداخته شد، لذا در تعميم نتايج

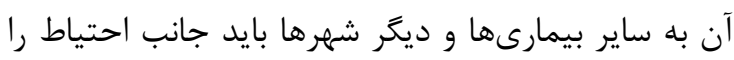
رعايت نمود. קيشنهاد مى شود كه در يروهشهاى آتى مطالعات يیخيرى

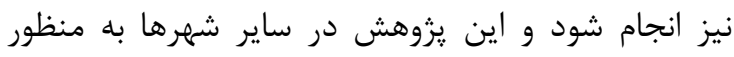

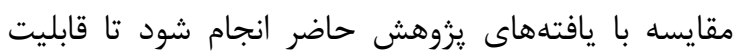
تعميميذيرى نتايج به طور دقيق مشخص گردد. با در نظر كرفتن تاثير متوسط اكت بر بهبود تمايل جنسى دئ در اين بن يزوهش، يیشنهاد مى گردد تا اثربخشى اين درمان با ديخر

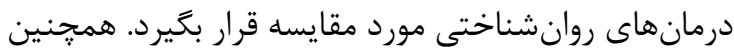
با توجه به نقش مهمم خانواده بر شرايط فرد بيمار، بهتر

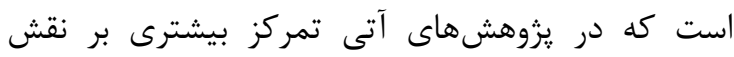

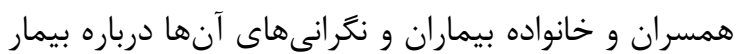

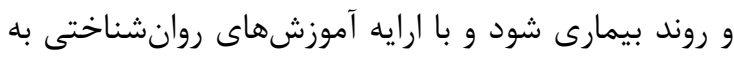

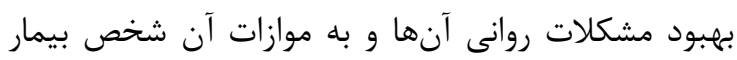
كمك شود. با توجه به محدوديتهاى كفته شده در يزوهش حاضر، اين مطالعه مىتواند به عنوان مقدمهاى براى فعاليتهاى يزوهشى وسيعتر و كاملتر در زمينه كاهش مشكلات روانشناختى بيماران مبتلا به سرطان

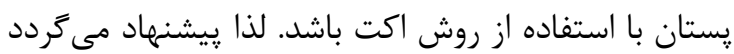
كه مطالعات ديخرى نيز در اين راستا انجام شود تا اعتبار

interventions to increase screening for breast, cervical, and colorectal cancers: nine updated systematic reviews for the guide to community preventive services. Am J Prev Med. 2012; 43 (1): 97-118. 
3. The first official cancer registration report based on the entire population of Iran. Deputy of research and technology. Ministry of health and education. 2015.

4. Wayteck L, Breckpot K, Demeester J, De Smedt SC, Raemdonck K. A personalized view on cancer immunotherapy. Cancer Lett. 2014; 352 (1): $113-25$.

5. Breast Cancer Facts \& Figures. American Cancer Society, Inc. http://www. cancer and careers. org/. 2014.

6. Turkman M. Comparison of the effectiveness of optimism and psychotherapy support on depression, anictrety and quality of life. Masters letter of psychology of Allameh Tabatabai university. 2012.

7. Khaje Aminian F, Ebrahimi M, Kumali M, Dolat Shahi B, Unesi J. Sexual function of women after mastectomy surgery-qualitative study. Journal Breast Diseases of Iran. 2014; 7: 3.

8. Burbie GE, Polinsky ML. Intimacy and sexuality after cancer treatment: restoring a sense of wholeness. J Psychosoc Oncol. 1992; 10:19-33.

9. Shahid Sales S, Hasanzadeh M, Saggade S, Davoud S. Comparison of sexual dysfunction in women with breast canser: case control study. Tehran University Medical Journal. 2017; 75(5): 350-7.

10. Sheppard LA, Ely S. Breast cancer and sexuality. The Breast J. 2008; 14: 176-81

11. Safarinejad MR. Female sexual dysfunction in population based study in Iran: prevalence and associated risk factors. International Journal of Impotence Research. 2006; 18: 382- 95.

12. Barni S, Mondin R. Sexual dysfunction in treated breast cancer patients. Annals of oncology. 1997; 8: 149-53.

13. Thors CL, Broeckel JA, Jacobsen PB. Sexual functioning in breast cancer survivors. Cancer Control. 2001; 8: 442-8.

14. Avis NE, Crawford S, Manuel J. Psychosocial problems among younger women with breast cancer. Psycho-Oncology. 2004; 13(5): 295308.

15. Hayati F, Shahsavari A, Mahmodi M. relation psychic convenience with individual factors of patients with breast cancer in hospitals of Tehran University of Medical Science. Journal of Iran breast diseases. 2009; 2(1): 23-8.

16. Honarparvaran N, Mirzaei Kia H, Nairi A, Lotfi M. Practical guide for therapists in
Acceptanc and commitment therapy. Omid Mehr; 2014.

17. Esmi Z. Effectivness of acceptance and commitment therapy on mental healt, quality of life and self-care behaviors in patients with breast cancer, Alzahra University, 2016.

18. Dehghani-Najvani B. Effectiivness of Acceptance and Commitment Therapy (ACT) on Depression and psychological flexibility in women with Breast cancer. University of Isfahan. Iran, 2013.

19. Abdollahzadeh, H., Kabirinasab, Y. The Effectiveness of acceptance and Commitment Therapy on internalized Shame and Sexual self-esteem of Women with Breast Cancer after Mastectomy Surgery. Quarterly Journal of Health Psychology, 2019; 7(28): 184-99.

20. Backchalaki N \& Mansouri A. The Effect of Acceptance and Commitment Therapy on the Sexual Function and Life Satisfaction in Women with Substance Use Disorders. MEJDS. 2017; 7 :89.

21. Kalal Y, Saraei F. Acceptanc \& commitment therapy on marital commitment and reconciliation, sexual satisfaction and satisfaction with womens lives. Journal of Principles of Mental Health. 2016; 18: 527-33.

22. Tabatabaei A, Sagadiyan E, Motamedi M. Acceptanc \& commitment therapy on sexual function, Sexual suggestive and dare to treat women with Sexual dysfunction. Journal of Behavioral Scinces Research. 2017; 15(1): 8492.

23. Cohen J. Statistical power analysis for the behavioral sciences .(2nd ed.). Hillsdale, NJ: Erlbaum; 1988.

24. Delavar A. Method of resignation in psychology and educational sciences. fourth edition; 2018.

25. Yousefi N, Farsani K, Shakiba A, Hemmati S, Nabavi Hesar J. Halbert index of sexual desire (HISD) questionnaire validation. CPAP. 2014; 2 (9):107-18

26. Hurlbert D. A comparative study using orgasm consistency training in the treatment of women reporting hypoactive sexual desire. Journal of Sex and Marital Therapy. 1993; 19: 44-55.

27. Asgarian F, Mirzaei M, Asgarian S, Jazayeri M. Epidemiology of Breast Cancer and the Age Distribution of Patients over a Period of Ten Years. Ijbd. 2016; 9 (1): 31-6.

28. Hajsadeghi Z, Bassak Nejad S, Razmjoo S. The Effectiveness of Acceptance and 
Commitment Group Therapy on Depression and Anxiety among women with breast cancer. Psj. 2017; 15 (4): 42-9.

29. Mogadamfar N, amraae R, asadi F, Amani O. The Efficacy of Acceptance and Commitment Therapy (ACT) on Hope and Psychological Well-being in Women with Breast Cancer under Chemotherapy. IJPN. 2018; 6 (5): 1-8.

30. Esmali Kooraneh A, Alizadeh M, Khanizadeh Balderlou K. The Effectiveness of Group Psychotherapy Based on Acceptance and Commitment on Quality of Life in Women with Breast Cancer. J Urmia Univ Med Sci. 2016; 27 (5): 365-74.

31. Sobouhi R, fatehizade M, ahmadi A, etemadi O. The Effect of Counseling Approach Based on Acceptance and Commitment Therapy
(ACT) on Amount of Marital Attributions and Marital Satisfaction in Women Admitted to Isfahan Cultural Centers. Knowledge \& Research in Applied Psychology. 2017; 18(1): 12-22.

32. Mohammadi e, Keshavarzi F, Farzad V, Salehi M. Effectivness of Acceptane and Commitment Therapy (ACT) on marital satisfaction on depressive women With marital confilicts. Knowledge \& Research in Applied Psychology. 2017; 17(2): 26-35.

33. Namani E. The effectiveness of group therapy based on acceptance and commitment(ACT) on communication beliefs and marital satisfaction of the incompatible women. Journal of Counseling Research. 2016; 15 (57): 58-80. 